\title{
Genetic resource impacts of habitat loss and degradation; reconciling empirical evidence and predicted theory for neotropical trees
}

\author{
AJ Lowe ${ }^{1}$, D Boshier ${ }^{2}, \mathrm{M}$ Ward ${ }^{1}$, CFE Bacles ${ }^{1,3}$ and C Navarro ${ }^{4}$ \\ ${ }^{1}$ School of Integrative Biology, University of Queensland, Brisbane, Queensland 4072, Australia; ${ }^{2}$ Department of Plant Sciences, Oxford \\ Forestry Institute, University of Oxford, South Parks Road, Oxford OX1 3RB, UK; ${ }^{3}$ Institute of Evolutionary Biology, Ashworth \\ Laboratories, School of Biological Sciences, The University of Edinburgh, Edinburgh EH9 3JT, UK; ${ }^{4}$ Centro Agrico Tropical de \\ Investigacia Ensena (CATIE), Cartago, Turrialba 7170, Costa Rica
}

\begin{abstract}
The theoretical impacts of anthropogenic habitat degradation on genetic resources have been well articulated. Here we use a simulation approach to assess the magnitude of expected genetic change, and review 31 studies of 23 neotropical tree species to assess whether empirical case studies conform to theory. Major differences in the sensitivity of measures to detect the genetic health of degraded populations were obvious. Most studies employing genetic diversity (nine out of 13) found no significant consequences, yet most that assessed progeny inbreeding (six out of eight), reproductive output (seven out of 10) and fitness (all six) highlighted significant impacts. These observations are in line with theory, where inbreeding is observed immediately following impact, but genetic diversity is lost slowly over subsequent generations, which for trees may take decades. Studies also highlight the ecological, not just genetic, consequences of habitat degradation that can
\end{abstract}

cause reduced seed set and progeny fitness. Unexpectedly, two studies examining pollen flow using paternity analysis highlight an extensive network of gene flow at smaller spatial scales (less than $10 \mathrm{~km}$ ). Gene flow can thus mitigate against loss of genetic diversity and assist in long-term population viability, even in degraded landscapes. Unfortunately, the surveyed studies were too few and heterogeneous to examine concepts of population size thresholds and genetic resilience in relation to life history. Future suggested research priorities include undertaking integrated studies on a range of species in the same landscapes; better documentation of the extent and duration of impact; and most importantly, combining neutral marker, pollination dynamics, ecological consequences, and progeny fitness assessment within single studies.

Heredity (2005) 95, 255-273. doi:10.1038/sj.hdy.6800725; published online 10 August 2005

Keywords: fragmentation; gene flow; genetic diversity; inbreeding; neotropical trees; selective logging

\section{Introduction}

Anthropogenic destruction of tropical forests has dramatically increased in recent decades, and the threat to tropical ecosystems is well articulated (eg Bawa and Seidler, 1998; White et al, 1999; Trejo and Dirzo, 2000; Ghazoul and McLeish, 2001). For biodiversity, the single most important impact of these activities is loss of primary habitat (Lira et al, 2003). However, the degradation of habitat also leaves a lasting legacy with which biota must cope if they are to continue to survive. The need for a more integrative approach to this problem, which combines ecology and population genetics, is evident (Sih et al, 2000; Young and Clarke, 2000). For trees, degradation of primary habitat results from two main processes, fragmentation of forest into patches following clearance and disturbance of habitat following extraction processes, such as selective logging.

Correspondence: AJ Lowe, School of Integrative Biology, University of Queensland, Brisbane, Queensland 4072, Australia.

E-mail: a.lowe@uq.edu.au

Received 13 December 2004; accepted 4 July 2005; published online 10 August 2005
Tropical trees are thought to be particularly vulnerable to the effects of habitat degradation due to their demographic and reproductive characteristics, including low density of occurrence, complex self-incompatible breeding systems, high rates of outcrossing (Cascante et al, 2002), and intimate interactions with pollinators and seed dispersers (Didham et al, 1996; Dick et al, 2003; Ward et al, 2005). Quantifying the impact of habitat degradation on remnant forest stands will not only help assess genetic and some ecological consequences of these changes but will also help to (1) ascertain the conservation value of remnant stands, (2) estimate future repercussions of tropical deforestation, and (3) formulate strategies for effective conservation and sustainable management of the genetic resources for species inhabiting degraded landscapes (Newton et al, 1999; White et al, 1999; Lemes et al, 2003; Lira et al, 2003).

Theoretically, population changes associated with habitat degradation lead to an erosion of genetic variation and increased interpopulation genetic divergence due to increased random genetic drift, elevated inbreeding, and reduced gene flow, where fragment/ population size and isolation fall below critical levels (Young et al, 1996). These changes are also predicted to 
affect population viability in the short and long term. In the short term, disturbed plant populations are expected to suffer increased disease and pest susceptibility (Barrett and Kohn, 1991), loss of incompatibility alleles, and fixation of deleterious alleles (Huenneke, 1991). In the long term, loss of genetic variation is expected to reduce the ability of populations to respond to changing selection pressures (Young et al, 1996).

However, do empirical studies always confirm theory? Do all cases of fragmentation and logging result in detrimental loss of genetic diversity as population theory predicts? Are there threshold levels of disturbance that cause higher levels of diversity loss in a wider range of species? What are the most sensitive methods to detect genetic perturbations following habitat loss and disturbance? There are now several reports that suggest that particular life history characteristics of some tree species (eg mating system, pollen and seed dispersal mechanisms) may help mitigate against genetic diversity loss in postfragmentation and disturbance landscapes (Dick, 2001; White et al, 2002). Such evidence also raises questions of which life history characteristics may make tree species vulnerable or resilient to genetic diversity loss following habitat change?

Here, we review the available literature documenting the genetic consequences of habitat degradation and assess whether case studies conform to theoretical predictions for both neutral markers and quantitative variation (31 studies of 23 species, for which 22 studies examined neutral genetic markers and 12 studies examined quantitative traits). This review is restricted to neotropical trees, as it is currently the best-studied tropical region for this topic, and was a region highlighted as a priority for review in a previous summary of temperate fragmentation studies (Young et al, 1996). We chose not to include here a relatively small number of additional studies from other tropical regions as significant bias, due to differences in environment and species evolutionary history, may have been unnecessarily introduced. For the purpose of this review, forest fragmentation and selective logging have been considered together, being both mechanisms that reduce individual density across populations, although in a variety of ways, depending on the particular disturbance. First, the theoretical expectations of habitat degradation are reviewed, and a simulation modelling approach is used to outline expectations for a range of neutral genetic marker statistics (allelic richness, heterozygosity, inbreeding coefficient, and genetic differentiation). The description of empirical studies has been subdivided into population-scale impacts, which include population diversity, genetic differentiation, and population level inbreeding, and individual effects, including gene dispersal, outcrossing rate, and progeny fitness. Based on this survey, some generalisations on the response of neotropical tree genetic resources to habitat degradation are highlighted, together with gaps in our current knowledge, problems with experimental and analytical design, and suggested directions of future research.

\section{Predicted theory}

It is fair to say that no population genetic theory of habitat fragmentation or disturbance has been developed per se, rather, expectations have been borrowed from well-established theory for the genetic behaviour of populations of small, finite size and for subdivided population, island biogeography and metapopulation theory. This approach is justified since the matrix of small islands of habitat created by fragmentation (Wilcove et al, 1986) corresponds to some of the assumptions underlying these models (eg stepping stone theory may be more appropriate than island models; MacArthur and Wilson, 2001). For neotropical forest species, a reduction in habitat patch size or population density is usually equivalent to a reduction in population size. Small populations in forest remnants are, therefore, expected to undergo genetic effects associated with a small population size.

Following is an overview of these expectations, which are summarized in Table 1 . In addition, a simulation modelling approach was taken to examine the genetic diversity and structural consequences of persistent small population sizes and the complicating influences of gene flow and inbreeding, the results of which are displayed in Figure 1.

\section{Changes in genetic diversity and structure}

As a consequence of habitat loss and degradation, severe loss of genetic variation is predicted. The severity of genetic bottleneck is determined by the severity of habitat loss, that is to say, the severity and duration of a reduction in population size (Barrett and Kohn, 1991). Following habitat disturbance, populations that remain small for many generations suffer loss of allelic diversity and random genetic drift (Figure 1; Barrett and Kohn, 1991; Ellstrand and Elam, 1993). While rare alleles will be the first to be lost, extended bottlenecks, acting over many generations, will cause loss of more common alleles, leading to a severe depletion of genetic diversity (Lande, 1988). Measures of allelic richness (R) are suitable for assessing short-term diversity loss, but for longer-term loss, involving commoner alleles, measures of gene diversity are more appropriate (Table 1; Lowe et al, 2004).

Habitat fragmentation and logging, by increasing spatial isolation between patches and individuals, are expected to reduce gene flow. Reductions in the proportion of immigrant genes, combined with drift and allelic loss in small populations will increase genetic differentiation among disturbed remnants (Figure 1; Slatkin, 1987; Young et al, 1996). A range of genetic differentiation measures (eg $F_{\mathrm{ST}}, R_{\mathrm{ST}}, P h i_{\mathrm{ST}}$ ) can be used to indirectly infer gene flow dynamics between remnant populations, although the persistence of preimpact individuals within a population may complicate analysis. Direct estimates of gene dispersal via pollen and seed are possible using paternity and parentage exclusion analyses (Ennos, 2001), and offer insights into contemporary patterns of gene flow between individuals and across different populations.

Gene flow in plants is idiosyncratic, varying greatly between species, populations, and seasons (Young et al, 1996), and its impact will depend on the level of genetic variation and its spatial organisation in source and sink populations (Ellstrand and Elam, 1993; Couvet, 2002). Removal of primary habitat also usually decreases the probability that migrant seeds will find suitable sites for 
establishment. Under such circumstances, pioneers or invasive weeds will be favoured and will increase in occurrence. If a species' life history profile is characterised by frequent extinction and colonisation events, the metapopulation is under threat of extinction if the two forces are not balanced (Lande, 1988). Even if site colonisation does occur, founder bottlenecks can drastically reduce diversity (Barrett and Kohn, 1991). Recent bottlenecks can be detected from molecular marker data using sign tests that compare observed and expected allelic diversity and heterozygosity (eg Luikart et al, 1998).

Following changes in population density and dispersal potential (which may be linked to the ecological consequences of degradation, eg loss of pollinating insect species), increased inbreeding is one of the main potentially deleterious outcomes of habitat degradation. Increased inbreeding (due to selfing or mating between relatives) redistributes individual allelic variation by reducing the proportion of heterozygosity (although this is not the only possible process, Slate et al, 2004). Comparison of observed and expected values of heterozygosity, and the inbreeding coefficient $\left(F_{\mathrm{IS}}\right)$, offer insights into population level inbreeding (Figure 1; Lowe et al, 2004). In addition, the rate of outcrossing $\left(t_{\mathrm{m}}\right.$; Ritland, 1986) can be estimated directly from openpollinated progeny arrays, as can the effective number of males contributing to seed families (correlation of outcrossed paternity; Ritland, 2002).

In line with the above theory, simulation modelling (Figure 1, methods described in legend) indicated that the most drastic genetic impacts of habitat loss and degradation are expected within very small, isolated populations that exhibit increased inbreeding. However, it was also clear that with even relatively low levels of gene flow between remnant populations, loss of diversity can significantly be mitigated by increasing effective population size (Figure 1). Another important observation is that changes in genetic diversity and differentiation following a decrease in population size take a number of generations to become apparent (Figure 1, and is related to population size), which is not the case for inbreeding coefficient that increases immediately in the first generation following the occurrence of selfing.

\section{Fitness implications}

Homozygosity at gene loci can expose deleterious recessive alleles to selection and may be associated with a reduction in individual fitness, that is, inbreeding depression (Charlesworth and Charlesworth, 1987; Hedrick, 1994; Husband and Schemske, 1997; Kirkpatrick and Jarne, 2000; Hansson and Westerberg, 2002; Keller and Waller, 2002). Inbreeding depression is expected to affect individual fecundity, establishment, and survival, and will ultimately impact on population viability (Hedrick, 1994; Keller and Waller, 2002). The exact population response, in terms of viability, depends on the composition of the population genetic load, which is in turn influenced by population size and history (Keller and Waller, 2002), the inheritance of mutations causing inbreeding depression and mating system dynamics (Bataillon and Kirkpatrick, 2000). Long-lived, historically outcrossing species, such as 
neotropical trees, are expected to harbour a high genetic load, as deleterious recessive alleles will be masked at multiple heterozygous loci, and increased inbreeding is expected to have severe effects on fitness (Griffin, 1991; Reinhartz and Les, 1994; Williams and Savolainen, 1996; although see Kirkpatrick and Jarne, 2000). Another complication of the consequences of longer-term isolation is that deleterious mutations are expected to be purged by selection decreasing the effects of inbreeding depression over time. The nature and degree of
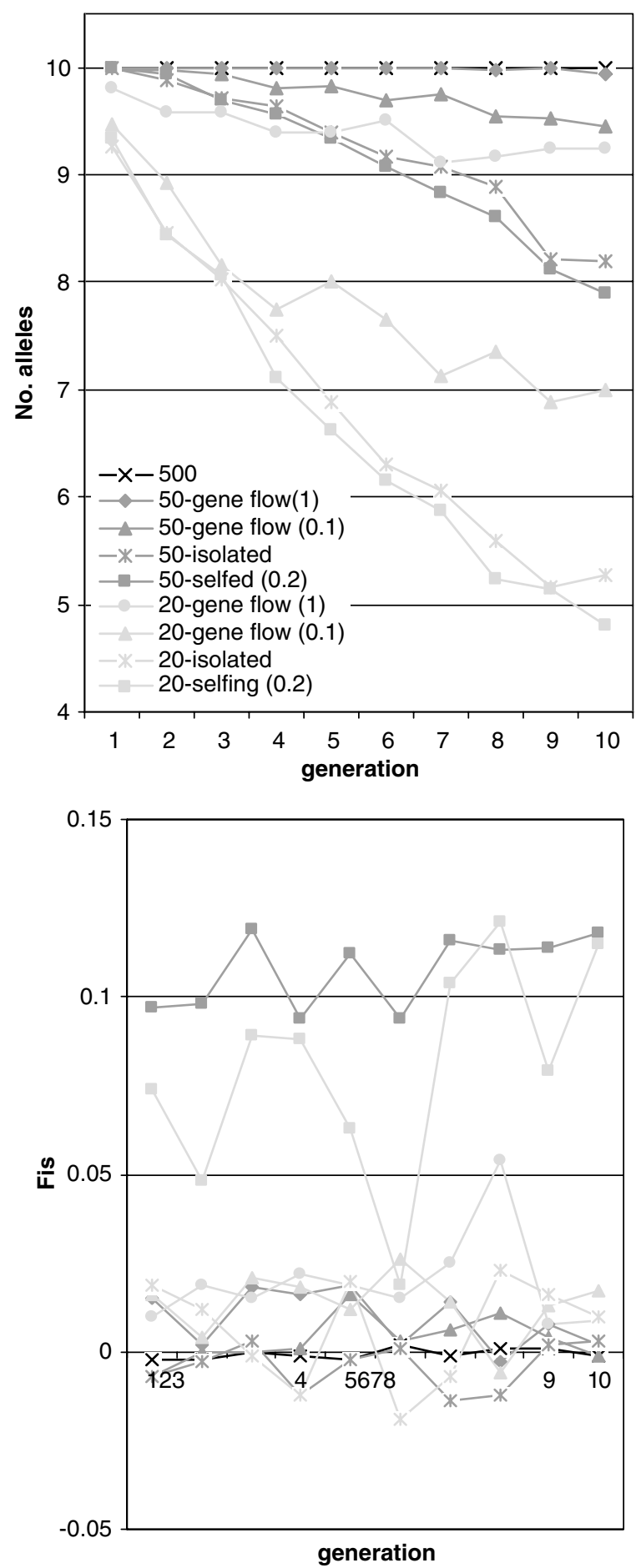

purging is expected to depend on the duration of inbreeding and genetic basis of inbreeding depression (Crnokrak and Barrett, 2003), although mildly deleterious alleles can persist despite strong selection, particularly for woody taxa with long generation times (Hedrick, 1994; Williams and Savolainen, 1996; Bataillon and Kirkpatrick, 2000). While the fitness impacts of inbreeding can be easily assessed in quantitative performance trials, there are relatively few studies of this nature for neotropical species as the following review
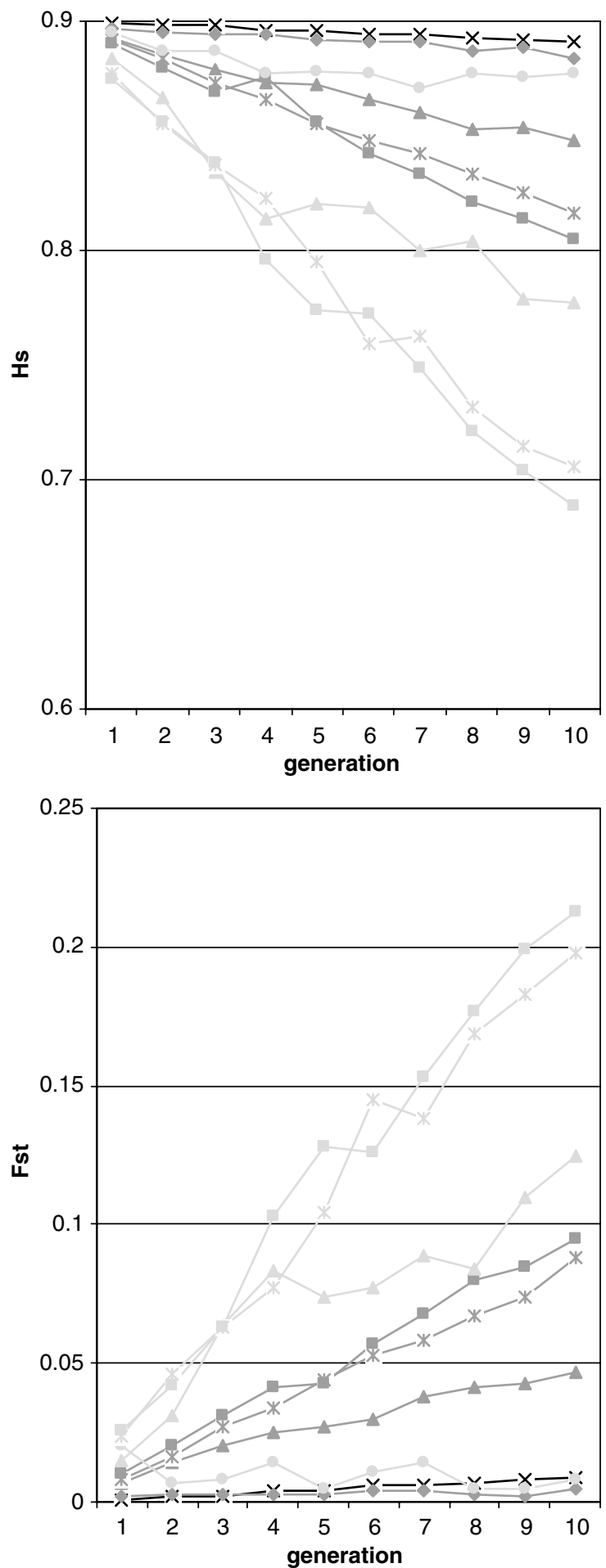
highlights, and is in contrast to the abundance of data on neutral markers.

Reduced pollen dispersal, due to increased spatial separation between individuals and populations, may lead to pollen limitation, which can cause lower seed set for isolated individuals. Even if sufficient pollen reaches an isolated tree to fertilise all potential ovules, a reduction in diversity of the pollen cloud, due to fewer pollen donors, can reduce family fitness by allowing fertilisations from self, related, or maladapted fathers (Rocha and Aguilar, 2001). Impacts following human disturbance may result from factors that are explicitly environmental or genetic, but are more generally likely to result from interactions between both. Thus, a reduction in seed set predicted from both fragmentation and logging may be due to one or a combination of a lack of pollination (eg from loss of pollinators), lack of compatible pollination (from increased self-pollination through restricted pollinator movement or a loss of incompatibility alleles owing to reduced population size), or inbreeding.

The impacts of deforestation and the consequent fragmentation of remnant forest are rarely random. Forest clearance for agriculture and human settlement concentrate on relatively flat, fertile sites, and therefore one can expect a preferential loss of populations adapted to these environments. Losses at the extremes of a species range are expected to reduce the range of adaptive genetic variance and hence adaptive potential. With loss of interior parts of a cline, particular genotypes might never be regenerated in any realistic time frame, even though no alleles are lost (Ledig, 1992). This may be manifest as species that were once widespread now being typically restricted to, and viewed as characteristic of, river courses or peaks (eg Anacardium excelsum, Ghazoul and McLeish, 2001). Provenance trials of a number of neotropical species show quantitative genetic variation across large ecological gradients, suggesting that selection pressures favour traits of potentially adaptive importance (eg Hodge and Dvorak, 2001). Typical of such findings is the differentiation between Caribbean and Pacific watershed Central American populations (eg Cedrela odorata and Cordia alliodora; Boshier and Henson, 1997; Navarro, 2002), and coastal and inland provenances (eg Pinus caribaea var. hondurensis; Gibson et al, 1983; Nikles et al, 1983; Birks and Barnes, 1990). Fragmentation and degradation of habitats has the potential to strengthen these local adaptations, which would lower the fitness of seed fertilised by immigrant pollen or the offspring of immigrant seed. Such a reduction in fitness may occur from the dilution of locally adapted alleles or the breakdown of coadapted gene complexes due to crossing between genotypes from different locations, known as outbreeding depression (Barrett and Kohn, 1991).

\section{Empirical studies}

\section{Population effects}

The majority of studies, which examined genetic diversity consequences (nine out of 13), found no significant difference between impacted and control populations. Of those studies which examined genetic differentiation or inbreeding coefficient within adult populations, equivocal results were recorded (two out of three studies found decreased differentiation and zero out of two increased inbreeding). One study which found no detectable genetic impact of forest fragmentation, and highlights some of the problems involved with large-scale comparative analyses, was a study of Caryocar brasiliense within continuous and fragmented forests of Brazil (Collevatti et al, 2001). High levels of microsatellite variation were found across all populations, and no difference for heterozygosity or inbreeding in fragmented compared to continuous forest samples. However, fragmentation of these populations had occurred 60 years prior to the study, and is thus a recent event, relative to the lifespan of the species. Therefore, since trees that had probably been present prior to anthropogenic disturbances were sampled for this study, the results may not reveal current rates of differentiation but rather the pre-existing genetic structure (Aldrich et al, 1998; Collevatti et al, 2001).

Apparently conflicting results were found for several species by different investigators. For example, Dayanandan et al (1999) used microsatellites to assess the allelic diversity of trees and seedlings from selectively logged (10 years prior to the study) and unlogged forest blocks of Carapa guianensis in Costa Rica. Although no evidence of inbreeding was found in any populations, allelic richness in the sapling cohort of the logged population was lower than that of the adult population, an effect not seen in unlogged populations. It was

Figure 1 Simulation of genetic diversity and structural consequences of persistent small population size and interactions with gene flow and inbreeding. Simulations were performed using EASYPOP (Balloux, 2001), for hermaphrodite individuals surveyed at 10 microsatellite loci (no linkage), each with 10 alleles (stepwise mutation model, rate $=0.01$ ) of equal frequency, distributed randomly across individuals of a population. For all simulations, nine populations were arranged in a $3 \times 3$ spatial array. Three population sizes were used of 500,50 , and 20 individuals. For simulations with population sizes of 50 and 20, two gene flow regimes, which followed a stepping stone model, were tested: one simulating panmixia between all nine populations (gene flow $=1$ ) and the second where $10 \%$ of individuals contributed to gene flow per generation (gene flow $=1$ ). Inbreeding was also varied in isolated population scenarios (where population size was 50 and 20 ), and individual inbreeding rates of $20 \%$ were allowed. Thus, a total of nine situations were simulated: (1) unconnected populations with 500 individuals and no inbreeding (500); (2) unconnected populations with 50 individuals and no inbreeding (50-isolated); (3) unconnected populations with 50 individuals and 20\% inbreeding (50-selfed (0.2)); (4) populations with 50 individuals, no inbreeding and panmictic gene flow between the nine neighbouring populations (50-gene flow (1)); (5) populations with 50 individuals, no inbreeding, and restricted gene flow between the nine neighbouring populations (50-gene flow (0.1)); (6) unconnected populations with 20 individuals and no inbreeding (20-isolated); (7) unconnected populations with 20 individuals and $20 \%$ inbreeding (20-selfed (0.2)); (8) populations with 20 individuals, no inbreeding, and panmictic gene flow between the nine neighbouring populations (20-gene flow (1)); (9) populations with 20 individuals, no inbreeding, and restricted gene flow between the nine neighbouring populations (20-gene flow (0.1)). Allele frequency data were analysed using FSTAT (Goudet, 2001) and allelic richness, heterozygosity $\left(H_{\mathrm{e}}\right)$, genetic differentiation $\left(F_{\text {st }}\right)$, and inbreeding coefficient $\left(F_{\text {is }}\right)$ were averaged over the simulated populations and are plotted for 10 generations. 
concluded that this reduced allelic richness in the isolated logged population was a result of restricted gene flow. However, an earlier study (Hall et al, 1994b), which sampled logged (6 years previously) and unlogged populations separated by up to $70 \mathrm{~km}$, found no evidence of changes in genetic differentiation within the seed families of six logged and three unlogged forests.

Gillies et al (1999) used random amplified polymorphic DNAs (RAPDs) to quantify genetic diversity within 20 populations of Swietenia macrophylla at a regional scale from Mexico to Panama. Genetic diversity values were tested for association with factors expected to influence diversity, including environment, proximity to putative refugia, and disturbance history. Of the factors tested, disturbance history was the only factor which was significantly correlated with a decrease in genetic diversity. Novick et al (2003) used microsatellite loci to assess genetic diversity and population structure in eight of the same $S$. macrophylla populations surveyed by Gillies et al (1999). However, while Gillies et al (1999) sampled mature S. macrophylla trees, Novick et al (2003) sampled seed, and found no difference in diversity between logged and undisturbed populations. Interestingly, the average number of alleles and expected heterozygosity were significantly lower in the Mesoamerican study of Novick et al (2003) than a study of southern Amazonian S. macrophylla populations, which screened the same loci (Lemes et al, 2003). The authors consider inbreeding and a historical legacy of colonisation from South America to be the most likely explanations for an excess of homozygosity in Mesoamerican populations. Céspedes et al (2003) examined genetic variation of S. macrophylla at four Costa Rican sites with different successional and disturbance histories (including fire and logging events between 50 and 100 years ago). High levels of allelic diversity were observed at all sites, and levels of genetic differentiation between populations were low. Despite the intensity of logging in the past, genetic diversity was not reduced, as indicated by allelic richness and observed heterozygosity.

One study which did find a clear genetic impact of forest fragmentation was an investigation of Terminalia amazonia in continuous forest in Belize compared to natural 1000-year-old forest fragments (Pither et al, 2003). RAPD analysis revealed that population differentiation was significantly higher and population diversity lower for fragmented compared to continuous forest populations, indicating a negative genetic impact due to longterm fragmentation.

\section{Individual effects}

For studies that documented inbreeding and gene flow responses at finer spatial scales, six out of eight found an increase in inbreeding (decreased $t_{\mathrm{m}}$ ) (Table 2). For example, Doligez and Joly (1997) studied the mating system of the rainforest tree Carapa procera in logged and unlogged rainforest plots in French Guiana. The sample plots were dispersed over an area of 300 ha, and logging had been performed 10 years prior to the study. Isozyme analysis revealed lower outcrossing rates in logged relative to undisturbed plots $\left(t_{\mathrm{m}}=0.63\right.$ and 0.85 , respectively).
Several studies have examined the extreme fragmentation impacts of isolated individuals. Cascante et al (2002) compared diversity and selfing rate for 17 isolated trees of Samanea saman (from disturbed sites along a $100 \mathrm{~km}$ transect), with 20 trees from a continuous population in a 7500 ha reserve in Costa Rica. Although the expected mean heterozygosity was similar in isolated and continuous population trees (0.230 and 0.190 , respectively), the effective self-fertilisation rate and inbreeding coefficient in progeny arrays was higher for isolated trees than for continuous population trees (effective self-fertilisation rate $=0.088$ and 0.010 , and $F_{\mathrm{IS}}=0.044$ and 0.005 , respectively). Fuchs et al (2003) found evidence for a reduction in genetic variability of progeny from isolated compared to continuous forest trees in a study of Pachira quinata in Costa Rica. Isozyme analysis revealed that the progeny of 15 isolated trees exhibited higher levels of relatedness and a tendency for lower levels of outcrossing than the progeny of 15 trees sampled from continuous forest populations $\left(r_{\mathrm{p}}=0.740\right.$ and 0.470 , respectively; $t_{\mathrm{m}}=0.777$ and 0.915 , respectively). Finally, Symphonia globulifera has been studied in a series of remnant forest patches within a 38.5 ha circular plot fragmented for the past 10-30 years in Costa Rica. Aldrich and Hamrick (1998) found that the proportion of progeny produced via selfing was higher for trees isolated in pasture than for trees in continuous forest ( $s=0.261$ and 0.098 , respectively). Microsatellite analysis also revealed significant inbreeding within seedlings, resulting in significant genetic differentiation, among fragmented forest populations $\left(R_{\mathrm{ST}}=0.210\right.$ for remnant forest; $R_{\mathrm{ST}}=0.005$ for continuous forest; Aldrich et al, 1998). Principle component analysis confirmed that a genetic bottleneck had occurred, with seedlings in remnant forest patches derived primarily from just two reproductively dominant, pasture trees.

An unexpected result of this survey was that two studies that used paternity assignment methods found increased pollen-mediated gene flow in impacted compared to nonimpacted landscapes (Table 2). For example, White et al (1999) investigated the level and distribution of genetic diversity within a highly fragmented population of Swietenia humilis in tropical dry forest in Honduras which had experienced extensive deforestation in the 1960s. Loss of low-frequency alleles at microsatellite loci was observed in fragmented blocks compared to a continuous stand, with the percentage of allelic loss increasing with decreased fragment size (White et al, 1999). However, despite severe fragmentation, indirect and direct estimates of gene flow revealed an extensive network of gene exchange over the spatial scale of the study $\left(5 \mathrm{~km}, R_{\mathrm{ST}}=0.032 ; N_{\mathrm{m}}=8.9\right)$, with high levels of genetic variation remaining across all fragments (mean $H_{\mathrm{E}}=0.5458$; White et al, 2002). The authors proposed that this contemporary gene flow is facilitated by pollinators moving between spatially isolated trees, which may be assisted by increased wind movement following canopy disruption. Such increased pollen flow appears to be facilitating remnant stands to persist as a metapopulation, maintaining and even augmenting genetic variation in S. humilis. In another interesting study, the canopy-emergent, Dinizia excelsa, thrives in Amazonian pastures and remnant fragments. Despite an absence of native pollinators, microsatellite assays of progeny indicated that high genetic diversity is 
Table 2 Number of studies that demonstrated a significant increase/decrease or no change in genetic diversity, inbreeding, genetic differentiation, gene flow, or fitness following habitat disturbance

\begin{tabular}{|c|c|c|c|c|c|}
\hline Measure & & Generation & Increased & Decreased & No change \\
\hline \multirow[t]{6}{*}{ Diversity } & \multirow[t]{3}{*}{ Allelic richness } & Adults & - & $2^{(16,23)}$ & $3^{(2,5,14)}$ \\
\hline & & Juveniles & - & $1^{(7)}$ & $2^{(2,5)}$ \\
\hline & & Progeny & - & - & $1^{(8)}$ \\
\hline & \multirow[t]{3}{*}{ Diversity index } & Adults & - & $2^{(13,16)}$ & $5^{(5,6,7,21,23)}$ \\
\hline & & Juveniles & - & - & $2^{(5,7)}$ \\
\hline & & Progeny & - & - & $3(4,11,15)$ \\
\hline \multirow[t]{3}{*}{ Gene flow } & & Adults & - & $2^{(14,16)}$ & $1^{(15)}$ \\
\hline & & Juveniles & - & - & - \\
\hline & & Progeny & $2^{(9,24)}$ & - & - \\
\hline \multirow[t]{3}{*}{ Inbreeding } & & Adults & - & - & $2^{(6,23)}$ \\
\hline & & Juveniles & $1^{(1)}$ & - & - \\
\hline & & Progeny & $4_{-}^{(4,9,10,11)}$ & - & $2^{(15, \underline{22})}$ \\
\hline Reproductive output & & & $2^{(3,8)}$ & $7^{(4,11,12,16,17,18, \underline{22})}$ & $1^{(3)}$ \\
\hline Progeny fitness & & & - & $6^{(\underline{4}, 17,18,19, \underline{20}, \underline{22})}$ & - \\
\hline
\end{tabular}

${ }^{1}$ Aldrich and Hamrick (1998); ${ }^{2}$ Aldrich et al (1998); ${ }^{3}$ Boshier et al (2004); ${ }^{4}$ Cascante et al (2002); ${ }^{5}$ Céspedes et al (2003); ${ }^{6}$ Collevatti et al (2001); ${ }^{7}$ Dayanandan et al (1999); ${ }^{8}$ Dick (2001); ${ }^{9}$ Dick et al (2003); ${ }^{10}$ Doligez and Joly (1997); ${ }^{11}$ Fuchs et al (2003); ${ }^{12}$ Ghazoul and McLeish (2001); ${ }^{13}$ Gillies et al (1999); ${ }^{14} \mathrm{Hall}$ et al (1994a); ${ }^{15} \mathrm{Hall}$ et al (1994b); ${ }^{16} \mathrm{Hall}$ et al (1996); ${ }^{17}$ Madriz (2004); ${ }^{18} \mathrm{Nason}$ and Hamrick (1997); ${ }^{19} \mathrm{Navarro}(2002) ;{ }^{20} \mathrm{Navarro}$ and Hernández (2004); ${ }^{21}$ Novick et al (2003); ${ }^{22}$ Rocha and Aguilar (2001); ${ }^{23}$ White et al (1999); ${ }^{24}$ White et al (2002).

Studies of fragmentation are indicated in italics, logging in bold and isolated tree studies are underlined.

maintained across habitats, with extensive gene flow across the pasture landscape, over distances up to $3.2 \mathrm{~km}$ (Dick, 2001). Pollen dispersal was also much more extensive in remnant forest patches compared to undisturbed forest (estimated mean pollen dispersal distances of 1509 and $212 \mathrm{~m}$, respectively). These unexpected outcomes were attributed to genetic rescue by an alien pollinator, the Africanized honeybees (Apis mellifera scutella), which has wider foraging behaviour than native forest dwelling bee pollinators (Dick et al, 2003). The only negative outcome of fragmentation noted for $D$. excelsa was increased self-fertilisation in progeny from remnant patches $(14 \%)$ compared to undisturbed forest (10\%; Dick et al, 2003).

\section{Fitness}

Of the potential fitness implications of habitat degradation, reproductive output is one of the easiest to quantify and reveals some disturbing patterns. Seven out of 10 studies identified deceased seed set for individuals in impacted compared to undisturbed habitats (Table 2). For example, a reduction in population size following fragmentation, combined with natural variation in flowering synchrony, resulted in lower seed set or failure to set fruit in Pithecellobium elegans (Hall et al, 1996). Similarly, Spondias mombin trees in small forest patches suffered significant reductions in fruit production and seed germination relative to large fragments or continuous forest (Nason and Hamrick, 1997). Pollination success and proportion of seed set for Anacardium excelsum was positively correlated with fragment size (Ghazoul and McLeish, 2001). The bee pollinators of this species were rarely noted to move between forest fragments and gene exchange through pollination occurred mainly within fragments, contribut- ing to reduced fertilisation and seed set of this selfincompatible species. Additionally, there was greater variation in fruit set in the small fragments, which may reflect variation between trees in the number of locally available compatible mates (Young et al, 2000). Despite receiving similar pollen loads on their stigmas, flowers on Samanea saman trees in continuous populations were more likely $(2.1 \%)$ to produce mature fruit than isolated trees $(0.4 \%)$, coinciding with lower levels of inbreeding (Cascante et al, 2002). Finally, a comparison of three stands of Honduran Pinus oocarpa with different densities (190, 120, seven trees per hectare) showed reduced reproductive output and progeny fitness in the sparsest stand for a number of variables, including proportion of filled seed, seed weight and seed viability, seed germination and initial growth (Madriz, 2004).

Not all studies observed a decrease in reproductive output as a consequence of habitat degradation, although this finding was strongly dependent on the developmental stage of observation. In undisturbed forest, the percentage fruit set of Pachira quinata was twice that of isolated trees separated by $500 \mathrm{~m}$ from conspecifics (Fuchs et al, 2003). However, seed production per fruit and overall fruit production per tree were not affected by fragmentation, where isolated trees tended to produce more flowers from larger crowns. Boshier et al (2004) found no impact of disturbance on fruit production in $P$. quinata. Indeed, the only site at which the species showed lower fruit production was in a forest remnant where the overmaturity of trees seemed to be the main factor leading to low flower production and fruit set. In Swietenia humilis, fruit production was more reliable and higher in disturbed than closed forest environments (Boshier et al, 2004), and the study of Dinizia excelsa (Dick, 2001) found that while inbreeding was increased, trees in 
habitat fragments produced over three times as many seeds as those in continuous forest.

Where undertaken, analysis of progeny array performance reveals some of the most worrying impacts of habitat degradation (all six studies documented, Table 2), and in several cases were detected when other measures had found no significant relationship. For example, despite exhibiting a full complement of seed set (James et al, 1998), progeny of Cedrela odorata grown from seed collected from isolated trees showed reduced vigour at 2 years of age, compared to progeny from primary or secondary forest (Navarro, 2002). Similarly, despite no evidence of inbreeding, progeny from Swietenia macrophylla trees isolated by more than $500 \mathrm{~m}$ showed reduced growth at 3.5 years compared with those from trees less than $100 \mathrm{~m}$ from conspecifics (Navarro and Hernández, 2004).

Other studies suggest that reductions in the vigour of progeny may be due to more complex factors than simply an increase in inbreeding. In Enterolobium cyclocarpum, trees from continuous forest were almost six times more likely to set fruits and produce more seeds per fruit than trees in pastures, and progeny from trees in continuous forest were more vigorous than those in pasture (Rocha and Aguilar, 2001). As there was no increase in inbreeding for isolated trees, the authors suggested that mechanisms that regulate progeny vigour are disrupted in pasture trees, such that less fit seed are allowed to mature. In undisturbed forest, a higher diversity of pollen results in selection for the fittest progeny at the pod maturation stage, whereas a reduction in the number of potential pollen donors will reduce selection possibilities and subsequent fitness in pasture trees. Population bottlenecks, through reproductive dominance, were also seen in S. globulifera, despite abundant and superficially healthy regeneration (Aldrich and Hamrick, 1998).

Increased gene flow following fragmentation or transplanting nonlocal seed raises concern over admixture of previously unconnected gene pools, and outbreeding depression (Ledig, 1992). Geographic differentiation for heritable fitness-related traits observed in provenance trials of many tree species provide indirect evidence for the potential effects of outbreeding depression when interpopulation distances are large. However, studies documenting the fitness consequences of such effects in neotropical trees are virtually nonexistent. There was no evidence of outbreeding depression in Swietenia humilis when populations in Central America separated by $500 \mathrm{~km}$ were crossed (Billingham, 1999). Pachira quinata only showed evidence of outbreeding depression (ie reduced seed set) when genetically distinct populations from as far apart as Honduras and Colombia were crossed (Billingham, 1999). This effect coincided with a natural disjunction in the species' distribution. Outbreeding depression may, however, not appear until the F2 generation, making observation in trees delayed and problematic.

\section{Conclusions}

The surveyed studies highlight major differences in the sensitivity of different measures to detect the genetic health of degraded populations. For example, most studies employing measures of genetic diversity (nine out of 13) found no significant consequence, yet most that assessed progeny arrays for levels of inbreeding (six out of eight), reproductive output (seven out of 10), and fitness (all six) highlighted significant impacts. These observations conform to theoretical and simulated predictions where genetic diversity will be lost slowly in post impact generations, which in the case of trees may be decades or centuries, but the impact of inbreeding may be observed immediately following disturbance. The studies also highlight the ecological, not just genetic, consequences of habitat degradation, where lack of pollination (eg from loss of pollinators), lack of compatible pollination (from increased selfpollination through restricted pollinator movement or a loss of incompatibility alleles owing to reduced population size), and/or inbreeding can cause reduced seed set and progeny fitness. Genetic marker studies may also be sensitive to bias from trees that survive the habitat degradation process, and may persist in a postimpacted landscape for hundreds if not thousands of years, acting as individual reservoirs of diversity. Such overlapping generations will further buffer diversity loss via intrapopulation gene flow, and if these individuals are included in postimpact analyses additional underestimation of genetic impact may result. Thus, while surveys of neutral genetic diversity may indicate substantial polymorphism, the genetic health of populations, as indicated by progeny fitness, may be in decline.

Studies that have examined gene flow show a dichotomous trend. Two studies that examined widely separated remnants (tens of km; Hall et al, 1994a, 1996) both found significant evidence for increased genetic differentiation. However, two studies that document pollen flow directly by paternity analysis (White et al, 2002; Dick et al, 2003) both highlighted the extensive network of gene flow that can exist for some species at smaller spatial scales (less than $10 \mathrm{~km}$ ). It is also clear from these latter studies that high levels of gene flow may help to mitigate against the loss of genetic diversity and thereby assisting long-term population viability (White et al, 1999, 2002; Figure 1). In this context, forest fragments and isolated trees may be important stepping stones for gene flow between forest fragments, providing connectivity and enhancing population variability (Chase et al, 1996; Dick, 2001; White et al, 1999, 2002). This view is rather far from the perception that remnant isolated trees are only the 'living dead', persisting by virtue of their longevity but contributing little to forest regeneration or the evolutionary future of species (Janzen, 1986). Very few studies directly linked gene flow dynamics in degraded landscapes with pollinator observations. One notable exception is the study of Dick (2001) which found that a pollinator shift in pasture compared to closed forest systems was responsible for increased gene flow under the former conditions. Several studies have speculated an increase in gene flow due to opening of the canopy following habitat degradation (eg White et al, 2002), which either increases wind dispersal or the accidental movement of weak flying pollinators, and needs to be an area of active future research.

There is much support for population size thresholds from theory (eg Young et al, 1996), but this aspect was difficult to assess in the current review. One of the main 
problems is the lack of consistent documentation of scale and size of remnants (number of individuals), scale and intensity of disturbance, and the duration or timing of impact. In addition, these parameters are highly variable between the different studies, as are individual species' life histories (eg pollen and seed dispersal capabilities, tolerance of selfing, colonisation guild), which will also dictate threshold levels. An interesting observation in this context is that the genetic consequences of the most extreme cases of fragmentation, isolated individuals, were spread throughout the columns of Table 2, with no discernable bias compared to studies of fragmented or logged populations. At present there is no basis to reject a threshold basis of population size (eg Young et al, 1996), but much more integrated work needs to be undertaken to examine if thresholds are similar across species and establish their critical determinants. Unfortunately there are also too few studies to draw firm conclusions on a relation between life history characteristics and genetic resilience to habitat degradation. Such generalisations are mainly complicated by differences between studies for scale of sampling, time since impact and severity of impact, and a lack of replication between different life history class representatives.

Although there is some evidence of reduced vigour of seed collected from isolated trees in agricultural landscapes, correct assignment of the observed changes to genetic or environmental causes may limit interpretation. Studies have generally only documented initial growth, where differential environmental effects on seed set and development may be influential. Changes in one measure may also be buffered by changes at another. For example, although the percentage of flowers setting seed may be reduced, which is observed by several studies reviewed here, the overall level of seed production per tree may not be reduced, due to a higher flower production from increased crown size, or greater stimulation of flower initials through increased canopy exposure (Fuchs et al, 2003). There are also a whole range of quantitative characters that can and have been used to assess the fitness of individuals raised in provenance and common garden trials, for example, progeny vigor, seed set as function of tree isolation, albinism, seed set, seed weight, germination (none, late, and variance), number of cotyledons, chlorophyll deficiencies, seedling height and dry weight. In assessing quantitative impacts care is required in determining how variables relate to sustainability of systems, be it in genetic, ecological, or other terms.

The risk posed to genetic resources following an anthropogenic reduction in range and variation of neotropical species was highlighted decades ago (eg Jasso, 1970). In view of this risk, many genetic resource provenance collections have been established (CAMCORE, Dvorak et al, 1996, 1999). However, can such collections continue to be sourced from the presently degraded landscape given findings of reduced reproductive output and vigour of progeny? Some studies indicate this may not be so problematic. For example, small, fragmented populations of Pinus tecunumanii (eg San Jeronimo in Guatemala which has reduced from 200 ha in 1980 to some 30 ha currently) still contain significant levels of quantitative genetic variation (Dvorak, personal communication). In addition, prove- nance material of Gliricidia sepium sourced from a small fragmented population in Guatemala (Retalhuleu) has shown consistently superior growth to other populations over a wide range of sites in the tropics (Dawson et al, 1997), and has provided a suitable basis for breeding programmes and seed orchards (Dunsdon and Simons, 1996). Thus, there may yet be hope for new germplasm conservation programmes that can only source material from degraded populations.

\section{Future research priorities}

The complex and varied results described here highlight the need for more detailed and integrated research to gain empirical evidence for theoretical predictions, or to allow for the development of new predictions. For future studies, some or all of the following should be attempted or considered:

1. Studies over small spatial scales should aim to examine genetic variation both before and after disturbance, consider greater numbers of replications and be conducted over a longer temporal scale, thus describing annual or seasonal variation. There are several large-scale studies of this type currently being conducted and we look forward to their outcomes (eg a joint research initiative between the Brazilian and British Governments - DENDROGENE).

2. Studies should aim to examine a variety of species with contrasting life history characteristics within the same landscape that contains populations that vary in size, isolation, and duration of impact. Only by undertaking such integrated studies will general recommendations on remnant population size thresholds be generated. Such studies would also highlight which life history traits are most important in mitigating genetic resource impacts of habitat degradation.

3. Sampling should target specific questions, rather than relying on opportunistic availability of material, which may compromise experimental design. For example, large-scale studies, especially for the purpose of developing species-specific conservation recommendations, should sample across the geographical range of a species, as has been standard in international forestry provenance trials (eg Gliricidia sepium, Hughes, 1998), and not just a few populations from a restricted area (Loveless, 2002; Pither et al, 2003).

4. The temporal scale of investigation, spatial scale of disturbance, and the generational cohort expected to bear genetic impacts needs careful consideration and detailed description. The landscape context of regeneration may also have an important impact on the long-term expression of genetic consequences of disturbance. For example, in mostly intact forest systems, very few saplings survive to maturity and so only ephemeral impacts may be observed following disturbance. However, where a whole cohort of saplings grow on to maturity, for example, secondary forest, the effects will be far longer lasting.

5. For a greater range of species, and for longer periods, the extent and circumstances under which open grown trees present substandard germplasm for regeneration and planting needs more study. 
6. Subsequent to fragmentation, selection pressures are expected to alter with changes in the forest environment, as a higher proportion of the remnant population experiences more open conditions of the forest edge and further anthropogenic disturbance. There are no data from neotropical species to show to what extent such changes are influencing the genetic makeup of populations.

7. Despite reductions in reproductive capacity or fitness, inbreeding actually increases genetic variance by exposing recessive alleles. It may thus also offer a route of rapid evolutionary change that is required under changing environments. There has also been discussion about the theoretical impact of logging on quantitative genetic variation and in particular the likelihood of dysgenic selection. Evidence of genetic erosion has been described by various experts in Swietenia mahagoni, although no quantitative information is available to support these suggestions (Styles, 1972, Newton et al, 1996). The difficulty in defining a baseline from which to monitor change, and the virtual lack of studies, means that there is little evidence to back up the theory (Ledig, 1992). These shortcomings should be examined in detail quantitatively.

8. More attention needs to be focused on changes in the behaviour of species involved in key ecological interactions, following disturbance in tropical forests. Increased tree isolation can result in reduced seed set due to changes in the foraging patterns of low vagility pollinators, even if pollinator population sizes are maintained. Few studies have actually documented these changes, and future studies should consider quantifying changes in wind patterns in addition to pollinator dynamics following habitat degradation (also see Ward et al, 2005).

9. Finally, it would be valuable for researchers to develop new analytical techniques (eg Cavers et al, 2005; Kremer et al, 2005) and models that evaluate the potential effects of fragmentation and selective logging on genetic resources. Modelling approaches should integrate population genetics and demographic processes to simulate the impact of different management scenarios on the genetic makeup of the species being modelled (eg ECOGENE, Degen et al, 2002). The construction of such models necessarily requires the collection of extensive reproductive, ecological, and genetic data to allow model validation. Once such data are amassed, management recommendations can be made on a species-by-species basis from model simulations. Extrapolation of simulated scenarios for other species with similar characteristics for which no baseline data are available may then be possible. In addition, simulation modellling holds the potential to allow comparisons between species with very different life history traits and between landscapes that have experienced very different levels of disturbance.

\section{Acknowledgements}

This review was conducted following the initial findings of the project 'Assessment of levels and dynamics of intraspecific genetic diversity of tropical trees' (funded by the EC under FP5 - International Cooperation, contract \# ERBIC18CT970149). We thank Stephen Cavers, two anonymous referees, and John Pannell for helpful comments to earlier versions of the manuscript.

\section{References}

Aldrich PR, Hamrick JL (1998). Reproductive dominance of pasture trees in a fragmented tropical forest mosaic. Science 281: 103-105.

Aldrich PR, Hamrick JL, Chavarriaga P, Kochert G (1998). Microsatellite analysis of demographic genetic structure in fragmented populations of the tropical tree Symphonia globulifera. Mol Ecol 7: 933-944.

Apsit VJ, Hamrick JL, Nason JD (2001). Breeding population size of a fragmented population of a Costa Rican dry forest tree species. J Hered 92: 415-420.

Balloux F (2001). EASYPOP (version 1.7), a computer program for the simulation of population genetics. $J$ Hered 92: 301-302.

Barrett SC, Kohn JR (1991). Genetic and evolutionary consequences of small population size in plants: implications for conservation. In: Falk DA, Holsinger KE (eds) Genetics and Conservation of Rare Plants. Oxford University Press: Oxford. pp 3-30.

Bataillon T, Kirkpatrick M (2000). Inbreeding depression due to mildly deleterious mutations in finite populations: size does matter. Genet Res 75: 75-81.

Bawa KS, Seidler R (1998). Natural forest management and conservation of biodiversity in tropical forests. Conserv Biol 12: $46-55$.

Billingham MR (1999). Genetic structure, localised adaptation and optimal outcrossing distance in two neotropical tree species. DPhil Thesis, University of Oxford.

Birks JS, Barnes RD (1990). Provenance variation in Pinus caribaea, P. oocarpa and P. patula spp. tecunumanii. Trop Fore Papers No. 21. Oxford Forestry Institute: Oxford.

Boshier DH, Gordon JE, Barrance AJ (2004). Prospects for Circa situm tree conservation in Mesoamerican dry forest agroecosystems. In: Frankie GW, Mata A, Vinson SB (eds) Biodiversity Conservation in Costa Rica, Learning the Lessons in the Seasonal Dry Forest. University of California Press: Berkeley. pp 210-226.

Boshier DH, Henson M (1997). Genetic Variation. In: Boshier DH, Lamb AT (eds) Cordia Alliodora: Genetics and Tree Improvement. Tropical Forestry Paper no. 36. Oxford Forestry Institute: Oxford. pp 39-65.

Cascante A, Quesada M, Lobo JA, Fuchs EJ (2002). Effects of dry tropical forest fragmentation on the reproductive success and genetic structure of the tree Samanea saman. Conserv Biol 16: 137-147.

Cavers S, Degen B, Caron H, Hardy O, Lemes M, Gribel R et al (2005). Optimal sampling strategy for estimation of spatial genetic structure in tree populations. Heredity 95: 281-289.

Céspedes M, Gutierrez MV, Holbrook NM, Rocha OJ (2003). Restoration of genetic diversity in the dry forest tree Swietenia macrophylla (Meliaceae) after pasture abandonmentt in Costa Rica. Mol Ecol 12: 3201-3212.

Charlesworth B, Charlesworth D (1987). Inbreeding depression and its evolutionary consequences. Annu Rev Ecol Syst 18: 237-268.

Chase MR, Moller C, Kesseli R, Bawa K (1996). Distant gene flow in tropical trees. Nature 383: 398-399.

Collevatti RG, Grattapaglia D, Hay JD (2001). Population genetic structure of the endangered tropical tree species Caryocar brasiliense, based on variability at microsatellite loci. Mol Ecol 10: 349-356.

Couvet D (2002). Deleterious effects of restricted gene flow in fragmented populations. Conserv Biol 16: 369-376. 
Crnokrak P, Barrett SCH (2003). Perspective: purging the genetic load: a review of the experimental evidence. Evolution 56: 2347-2358.

Dawson IK, Waugh R, Simons AJ, Powell W (1997). Simple sequence repeats provide a direct estimate of pollenmediated gene dispersal in a tropical tree Gliricidia sepium. Mol Ecol 6: 179-183.

Dayanandan S, Dole J, Bawa K, Kesseli R (1999). Population structure delineated with microsatellite markers in fragmented populations of a tropical tree, Carapa guianensis (Meliaceae). Mol Ecol 8: 1585-1592.

Degen B, Roubik DW, Loveless MD (2002). Impact of selective logging and forest fragmentation on the seed cohorts of an insect-pollinated tropical tree. In: Degen B, Loveless MD, Kremer A (eds) Modelling and Experimental Research on Genetic Processes in Tropical and Temperate Forests. Meeting Proceedings 18th-22nd September 2000 Kourou, French Guiana. Embrapa Amazonia Oriental: Belem, PA. pp 108-119.

Dick CW (2001). Genetic rescue of remnant tropical trees by an alien pollinator. Proc $R$ Soc Lond B Biol Sci 268: 23912396.

Dick CW, Etchelecu G, Austerlitz F (2003). Pollen dispersal of tropical trees (Dinizia excelsa: Fabaceae) by native insects and African honeybees in pristine and fragmented Amazonian rainforest. Mol Ecol 12: 753-764.

Didham RK, Ghazoul J, Stork NE, Davis AJ (1996). Insects in fragmented forests: a functional approach. Trends Ecol Evol 11: $255-261$

Doligez A, Joly HI (1997). Mating system of Carapa procera (Meliaceae) in the French Guiana tropical forest. Am J Bot 84: 461-470.

Dunsdon AJ, Simons AJ (1996). Provenance and progeny trials. In: Stewart JL, Allison GE, Simons AJ (eds) Gliricidia sepium: Genetic Resources for Farmers. Tropical Forestry Papers No. 33. Oxford Forestry Institute: Oxford. pp 93-118.

Dvorak WS, Donahue JK, Hodge GR (1996). Fifteen years of ex situ gene conservation of Mexican and Central American forest species by the CAMCORE cooperative. Forest Genet Resource Bull 24: 15-21.

Dvorak WS, Hamrick JL, Hodge GR (1999). Assessing the sampling efficiency of ex situ gene conservation in natural pine populations in Central America. Forest Genet 6: $21-28$.

Ellstrand NC, Elam DR (1993). Population genetic consequences of small population size: implications for plant conservation. Annu Rev Ecol Syst 24: 217-242.

Ennos RA (2001). Inferences about spatial processes in plant populations from the analysis of molecular markers. In: Silvertown J, Antonovics J (eds) Integrating Ecology and Evolution in a Spatial Context. Blackwell Science: Oxford. pp 45-71.

Fuchs EJ, Lobo JA, Quesada M (2003). Effects of forest fragmentation and flowering phenology on the reproductive success and mating patterns of the tropical dry forest tree Pachira quinata. Conserv Biol 17: 149-157.

Ghazoul J, McLeish M (2001). Reproductive ecology of tropical forest trees in logged and fragmented habitats in Thailand and Costa Rica. Plant Ecol 153: 335-345.

Gibson GL, Barnes RD, Berrington J (1983). Provenance productivity in Pinus caribaea and its interaction with environment. Commonwealth Forest Rev 62: 93-106.

Gillies ACM, Navarro C, Lowe AJ, Newton AC, Hernández M, Wilson J et al (1999). Genetic diversity in Mesoamerican populations of mahogany (Swietenia macrophylla), assessed using RAPDs. Heredity 82: 722-732.

Goudet J (2001). FSTAT, a program to estimate and test gene diversities and fixation indices (version 2.9.3). http:// www.unil.ch/izea/softwares/fstat.html.

Griffin AR (1991). Effects of inbreeding on growth of forest trees and implications for management of seed supplies for plantation programs. In: Bawa KS, Hadley M (eds) Reproductive Ecology of Tropical Forest Plants. Man and the Biosphere Series. Unesco/Parthenon Publishing: Paris and Carnforth. Vol 7, pp 355-374.

Hall P, Chase MR, Bawa KS (1994a). Low genetic variation but high population differentiation in a common forest species. Conserv Biol 8: 471-482.

Hall P, Orrell LC, Bawa KS (1994b). Genetic diversity and mating system in a tropical tree, Carapa guianensis (Meliaceae). Am J Bot 81: 1104-1111.

Hall P, Walker S, Bawa K (1996). Effects of forest fragmentation on genetic diversity and mating system in a tropical tree, Pithecellobium elegans. Conserv Biol 10: 757-768.

Hansson B, Westerberg L (2002). On the correlation between heterozygosity and fitness in natural populations. Mol Ecol 11: $2467-2474$.

Hedrick PW (1994). Purging inbreeding depression and the probability of extinction: full-sib mating. Heredity 73 363-372.

Hodge GR, Dvorak WS (2001). Genetic parameters and provenance variation of Pinus caribaea var. hondurensis in 48 international trials. Can J Forest Res 31: 496-511.

Huenneke LF (1991). Ecological implication of genetic variation in plant population. In: Falk DA, Holsinger KE (eds) Genetics and Conservation of rare plants. Oxford University press: Oxford. pp 31-44.

Hughes CE (1998). Leucaena - A Genetic Resources Handbook. Tropical Forestry Paper No. 37. Oxford Forestry Institute: Oxford.

Husband BC, Schemske DW (1997). The effect of inbreeding in diploid and tetraploid populations of Epilobium angustifolium (Onagraceae): implications for the genetic basis of inbreeding depression. Evolution 51: 737-746.

James T, Vege S, Aldrich P, Hamrick JL (1998). Mating systems of three tropical dry forest tree species. Biotropica 30: 587-594.

Janzen DH (1986). Blurry catastrophes. Oikos 47: 1-2.

Jasso JM (1970). Impact of silviculture on forest gene resources. Unasylva 24: 70-75.

Keller L, Waller DM (2002). Inbreeding effects in wild populations. Trends Ecol Evol 17: 230-241.

Kirkpatrick M, Jarne P (2000). The effects of a bottleneck on inbreeding depression and the genetic load. Am Nat 155 154-167.

Kremer A, Caron H, Cavers S, Colpaert N, Gheysen L, Gribel R et al (2005). Monitoring genetic diversity in tropical trees with multilocus dominant markers. Heredity 95: 274-280.

Lande R (1988). Genetics and demography in biological conservation. Science 241: 1455-1460.

Ledig FT (1992). Human impacts on genetic diversity on forest ecosystems. Oikos 63: 87-108.

Lemes MR, Gribel R, Proctor J, Grattapaglia D (2003). Population genetic structure of mahogany (Swietenia macrophylla King, Meliaceae) across the Brazilian Amazon, based on microsatellite loci: implications for conservation. Mol Ecol 12 2875-2883.

Lira CF, Cardoso SRS, Ferreira PCG, Cardoso MA Provan J (2003). Long-term population isolation in the endangered tropical tree species Caesalpinia echinata Lam. revealed by chloroplast microsatellites. Mol Ecol 12: 3219-3225.

Loveless MD (2002). Genetic diversity and differentiation in tropical trees. In: Degen B, Loveless MD, Kremer A (eds) Modelling and Experimental Research on Genetic Processes in Tropical and Temperate Forests. Meeting Proceedings 18th-22nd September 2000 - Kourou, French Guiana. Embrapa Amazonia Oriental: Belem, PA. pp 3-30.

Lowe AJ, Harris SA, Ashton P (2004). Ecological Genetics: Design, Analysis and Application. Blackwells: Oxford, 326pp.

Luikart G, Sherwin WB, Steele B, Allendorf FW (1998). Usefulness of molecular markers for detecting popula- 
tion bottlenecks and monitoring genetic change. Mol Ecol 7: 963-974.

MacArthur RH, Wilson EO (2001). The Theory of Island Biogeography. Princeton University Press: New Jersey.

Madriz JP (2004). Cambios genéticos en la regeneración natural de Pinus oocarpa var. oocarpa Schiede ex Schltdl, causado por el manejo forestal y la deforestación. Comayagua Honduras, América Central - un estudio observacional. Unpublished MSc Thesis. Centro Agronómico Tropical de Investigación y Enseñanza CATIE, Costa Rica

Nason JD, Hamrick JL (1997). Reproductive and genetic consequences of forest fragmentation: two case studies of neotropical canopy trees. I Hered 88: 264-276.

Navarro C (2002). Genetic resources of Cedrela odorata L. and their efficient use in Mesoamerica. PhD thesis, University of Helsinki.

Navarro C, Hernández G (2004). Progeny test analysis and population differentiation of Mesoamerican mahogany (Swietenia macrophylla). Rev Agronom Costarricense 28 (in press).

Newton AC, Allnut TR, Gillies ACM, Lowe AJ, Ennos RA (1999). Molecular phylogeography, intraspecific variation and the conservation of tree species. Trends Ecol Evol 14: 140-145.

Newton AC, Cornelius JP, Baker P, Gillies ACM, Hernández M, Ramnarine $\mathrm{R}$ et al (1996). Mahogany as a genetic resource. Bot J Linn Soc 122: 61-73.

Nikles DG, Spidy T, Rider EJ (1983). Genetic variation in windfirmness among provenances of Pinus caribaea Mor. Var. hondurensis Barr. and Golf. in Queensland. Silvicultura 8: 126-130.

Novick RR, Dick CW, Lemes MR, Navarro C, Caccone A Bermingham E (2003). Genetic structure of Mesoamerican populations of Big-leaf mahogany (Switenia macrophylla) inferred from microsatellite analysis. Mol Ecol 12: 28852893.

Pither R, Shore JS, Kellman M (2003). Genetic diversity of the tropical tree Terminalia amazonia (Combretaceae) in naturally fragmented populations. Heredity 91: 307-313.

Reinhartz JA, Les DH (1994). Bottleneck induced dissolution of self-incompatibility and breeding systems consequences in Aster furcatus (Asteraceae). Am I Bot 81: 446-455.

Rocha OJ, Aguilar G (2001). Reproductive biology of the dry forest tree Enterolobium cyclocarpum (Guanacaste) in Costa Rica: a comparison between trees left in pasture and tress in continuous forest. Am J Bot 88: 1607-1614.

Ritland K (1986). Joint maximum likelihood estimation of genetic and mating structure using open-pollinated progenies. Biometrics 42: 25-43.

Ritland K (2002). Extensions of models for the estimation of mating systems using $n$ independent loci. Heredity $\mathbf{8 8}$ 221-228.
Sih A, Jonsson BG, Luikart G (2000). Habitat loss: ecological, evolutionary and genetic consequences. Trends Ecol Evol 15: 132-134.

Slate J, David P, Dodds KG, Veenliet BA, Glass BC, Broad TE et al (2004). Understanding the relationship between the inbreeding coefficient and multilocus heterozygosity: theoretical expectations and empirical data. Heredity 93: 255-265.

Slatkin M (1987). Gene flow and the geographic structure of natural populations. Science 236: 787-792.

Styles BT (1972). The flower biology of the Meliaceae and its bearing on tree breeding. Silv Genet 21: 175-182.

Trejo I, Dirzo R (2000). Deforestation of seasonally dry tropical forest: a national and local analysis in Mexico. Biol Conserv 94: 133-142.

Ward M, Dick CW, Gribel R, Lemes M, Caron H, Lowe AJ (2005). To self, or not to self... A review of outcrossing and pollen-mediated gene flow in neotropical trees. Heredity 95: 246-254.

White GM, Boshier DH, Powell W (1999). Genetic variation within a fragmented population of Swietenia humilis Zucc. Mol Ecol 8: 1899-1909.

White GM, Boshier DH, Powell W (2002). Increased pollen flow counteracts fragmentation in a tropical dry forest: an example from Swietenia humilis Zuccarini. Proc Nat Acad Sci USA 99: 2038-2042.

Wilcove DS, McLellan CH, Dobson AP (1986). Habitat fragmentation in the temperate zone. In: Soulé M (ed) Conservation Biology. Sinauer Associates: Sunderland Mass. pp 237-256.

Williams CG, Savolainen O (1996). Inbreeding depression in conifers: implications for breeding strategy. Forest Sci 42: 102-117.

Young A, Boyle T, Brown AHD (1996). The population genetic consequences of habitat fragmentation for plants. Trends Ecol Evol 11: 413-418.

Young A, Clarke G (eds) (2000). Genetics, Demography and the Viability of Fragmented Populations. Cambridge University Press: Cambridge.

Young AG, Brown AHD, Murray BG, Thrall PH, Miller CH (2000). Genetic erosion, restricted mating and reduced viability in fragmented populations of the endangered grassland herb Rutidosis leptorrhynchoides. In: Young AG, Clarke GM (eds) Genetics, Demography and Viability of Fragmented Populations. Cambridge University Press: Cambridge. pp 335-359.

\section{Appendix}

See Table A1. 


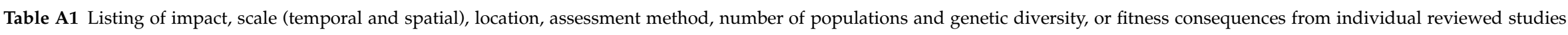

\begin{tabular}{|c|c|c|c|c|c|c|c|c|c|c|c|}
\hline \multirow[t]{2}{*}{ Species } & \multirow[t]{2}{*}{ Impact } & \multirow{2}{*}{$\begin{array}{l}\text { Time since } \\
\text { impact began }\end{array}$} & \multirow{2}{*}{$\begin{array}{l}\text { Material } \\
\text { collected }\end{array}$} & \multirow[t]{2}{*}{ Location } & \multirow[t]{2}{*}{ Marker type } & \multirow{2}{*}{$\begin{array}{l}\text { Number of } \\
\text { populations }\end{array}$} & \multicolumn{3}{|c|}{ Response } & \multirow[t]{2}{*}{ Comments } & \multirow[t]{2}{*}{ Reference } \\
\hline & & & & & & & Diversity & Inbreeding & Gene flow & & \\
\hline $\begin{array}{l}\text { Anacardium } \\
\text { excelsum }\end{array}$ & Fragmentation & & Seeds & $\begin{array}{l}\text { Northwestern } \\
\text { Costa Rica }\end{array}$ & $\begin{array}{l}\text { Reproductive } \\
\text { traits: } \\
\text { pollination } \\
\text { success, initial } \\
\text { and mature } \\
\text { seed set }\end{array}$ & $\begin{array}{l}11 \text { fragments } \\
\text { varying in } \\
\text { size }(0.3 \text { ha to } \\
>500 \text { ha and } \\
\text { isolation } \\
(<500 \mathrm{~m}, 0.5- \\
2 \mathrm{~km},>2 \mathrm{~km})\end{array}$ & \multicolumn{3}{|c|}{$\begin{array}{l}\text { Pollination success and initial seed set positively correlated } \\
\text { with fragment size. Mature seed set variable, but not } \\
\text { correlated with fragment size }\end{array}$} & & $\begin{array}{l}\text { Ghazoul } \\
\text { and McLeish } \\
(2001)\end{array}$ \\
\hline $\begin{array}{l}\text { Carapa } \\
\text { guianensis }\end{array}$ & Logging & 6 years & Seeds & Costa Rica & $\begin{array}{l}\text { Allozymes: } \\
\text { Six polymorphic } \\
\text { loci, } \\
10 \text { monomorphic } \\
\text { loci }\end{array}$ & $\begin{array}{l}\text { Three } \\
\text { unlogged } \\
\text { populations } \\
\text { located in a } \\
1510 \text { ha reserve } \\
\text { ( }>15 \text { trees/ha) } \\
\text { Six logged } \\
\text { populations } \\
\text { separated by } \\
\text { up to } 70 \mathrm{~km}\end{array}$ & $\begin{array}{l}H=0.12-0.13 \\
H=0.11-0.12\end{array}$ & $t_{\mathrm{m}}=0.967$ & $\begin{array}{l}F_{\mathrm{ST}}=0.046 \\
N_{\mathrm{m}}=4.10\end{array}$ & \multicolumn{2}{|c|}{$\begin{array}{l}\text { No differentiationHall et al } \\
\text { between logged (1994b) } \\
\text { and unlogged } \\
\text { forests: } \\
\text { High gene flow } \\
\text { due to seed } \\
\text { dispersal }\end{array}$} \\
\hline C. guianensis & Logging & 10 years & $\begin{array}{l}\text { Leaves from } \\
\text { adults and } \\
\text { saplings }\end{array}$ & Costa Rica & $\begin{array}{l}\text { Microsatellites: } \\
\text { Three loci }\end{array}$ & $\begin{array}{l}\text { Two logged } \\
\text { populations } \\
\text { located } 40 \\
\text { and } 44 \mathrm{~km} \\
\text { from reserve } \\
\text { (11 and } 15 \\
\text { trees/ha) }\end{array}$ & $\begin{array}{l}H_{\mathrm{E}}=0.26-0.87 \\
\text { (adults); } \\
H_{\mathrm{E}}=0.12-0.82 \\
\text { (saplings); } \\
H_{\mathrm{O}}=0.22-0.86 \\
\text { (adults); } \\
H_{\mathrm{O}}=0.13-0.84 \\
\text { (saplings) } \\
H_{\mathrm{E}}=0.36-0.86 \\
\text { (adults); } \\
H_{\mathrm{E}}=0.27-0.89 \\
\text { (saplings); } \\
H_{\mathrm{O}}=0.35-0.83 \\
\text { (adults); } \\
H_{\mathrm{O}}=0.31-0.93 \\
\text { (saplings) }\end{array}$ & & & $\begin{array}{l}\text { Low allelic } \\
\text { richness in the } \\
\text { isolated logged } \\
\text { population: } \\
\text { Restriction of } \\
\text { gene flow }\end{array}$ & $\begin{array}{l}\text { Dayanandan } \\
\text { et al (1999) }\end{array}$ \\
\hline C. procera & Logging & 10 years & Seeds & French Guiana & $\begin{array}{l}\text { Isozymes: } \\
10 \text { loci }\end{array}$ & $\begin{array}{l}\text { Seven } \\
\text { unlogged } \\
\text { plots within a } \\
300 \text { ha } \\
\text { silvicultural } \\
\text { trial population } \\
\text { Nine logged } \\
\text { plots within a } \\
300 \text { ha } \\
\text { silvicultural } \\
\text { trial population }\end{array}$ & & $t_{\mathrm{m}}=0.63$ & & $\begin{array}{l}\text { Lower } \\
\text { outcrossing in } \\
\text { logged plots }\end{array}$ & $\begin{array}{l}\text { Doligez and } \\
\text { Joly (1997) }\end{array}$ \\
\hline
\end{tabular}


Table A1 Continued

\begin{tabular}{|c|c|c|c|c|c|c|c|c|c|c|c|}
\hline \multirow[t]{2}{*}{ Species } & \multirow[t]{2}{*}{ Impact } & \multirow{2}{*}{$\begin{array}{l}\text { Time since } \\
\text { impact began }\end{array}$} & \multirow{2}{*}{$\begin{array}{l}\text { Material } \\
\text { collected }\end{array}$} & \multirow[t]{2}{*}{ Location } & \multirow[t]{2}{*}{ Marker type } & \multirow{2}{*}{$\begin{array}{l}\text { Number of } \\
\text { populations }\end{array}$} & \multicolumn{3}{|c|}{ Response } & \multirow[t]{2}{*}{ Comments } & \multirow[t]{2}{*}{ Reference } \\
\hline & & & & & & & Diversity & Inbreeding & Gene flow & & \\
\hline $\begin{array}{l}\text { Caryocar } \\
\text { brasiliense }\end{array}$ & Fragmentation & 60 years & $\begin{array}{l}\text { Leaves from } \\
\text { adults and } \\
\text { seeds }\end{array}$ & Brazil & $\begin{array}{l}\text { Microsatellites: } \\
10 \text { loci }\end{array}$ & $\begin{array}{l}\text { Five } \\
\text { continuous } \\
\text { populations } \\
\text { with a total } \\
\text { sample area } \\
\text { of } 20.2 \mathrm{~km}^{2} \\
\text { Five } \\
\text { fragmented } \\
\text { populations } \\
\text { with a total area } \\
\text { of } 211.3 \mathrm{~km}^{2}\end{array}$ & $\begin{array}{l}H_{\mathrm{E}}=0.855-0.882 ; \\
H_{\mathrm{O}}=0.709-0.800 \\
H_{\mathrm{E}}=0.751-0.889 ; \\
H_{\mathrm{O}}=0.697-0.719\end{array}$ & $f=0.092-0.172$ & $R_{\mathrm{ST}}=0.29$ & $\begin{array}{l}\text { No observed } \\
\text { response due } \\
\text { to sampling of } \\
\text { adults present } \\
\text { prior to } \\
\text { fragmentation }\end{array}$ & $\begin{array}{l}\text { Collevatti } \\
\text { et al (2001) }\end{array}$ \\
\hline $\begin{array}{l}\text { Cedrela } \\
\text { odorata }\end{array}$ & $\begin{array}{l}\text { Logging/ } \\
\text { habitat } \\
\text { destruction }\end{array}$ & & Seeds & $\begin{array}{l}\text { Mesoamerica } \\
\text { Mexico-Panamá }\end{array}$ & $\begin{array}{l}\text { Quantitative } \\
\text { traits; height, } \\
\text { diameter, } \\
\text { number of } \\
\text { shoots after } \\
\text { shoot borer } \\
\text { attack } \\
\text { (summation of } 18 \\
\text { measurements) }\end{array}$ & $\begin{array}{l}17 \text { grasslands } \\
\text { and home } \\
\text { orchards, five } \\
\text { primary or } \\
\text { secondary } \\
\text { forests. Trees } \\
\text { classified as i. } \\
\text { isolated mother } \\
\text { tree (no other } \\
\text { conspecifics at } \\
<500 \mathrm{~m} \text { ), ii. } \\
\text { semiisolated } \\
\text { (other trees } \\
\geqslant 100 \mathrm{~m}) \text {, iii. } \\
\text { trees in clusters } \\
\text { or associated } \\
\text { with }>2 \text { trees in } \\
\text { radius }<100 \mathrm{~m}\end{array}$ & \multicolumn{3}{|c|}{$\begin{array}{l}\text { Reduction in growth of progeny from isolated trees } \\
\text { compared to continuous population trees }\end{array}$} & & $\begin{array}{l}\text { Navarro } \\
\text { (2002) }\end{array}$ \\
\hline $\begin{array}{l}\text { Dinizia } \\
\text { excelsa }\end{array}$ & Fragmentation & 15-20 years & $\begin{array}{l}\text { Leaves from } \\
\text { adults and } \\
\text { seeds }\end{array}$ & Brazil & $\begin{array}{l}\text { Microsatellites: } \\
\text { Five loci } \\
80 \text { alleles }\end{array}$ & $\begin{array}{l}\text { Two } \\
\text { continuous } \\
\text { populations } \\
\text { Remnants in } \\
\text { three ranches }\end{array}$ & $\begin{array}{l}17-28 \text { alleles per } \\
\text { locus } \\
15-37 \text { alleles per } \\
\text { locus }\end{array}$ & & $\begin{array}{l}\text { Gene flow over as } \\
\text { much as } 3.2 \mathrm{~km}\end{array}$ & $\begin{array}{l}\text { Extensive gene } \\
\text { flow due to alien } \\
\text { pollinator }\end{array}$ & Dick (2001) \\
\hline D. excelsa & Fragmentation & 15-20 years & $\begin{array}{l}\text { Leaves from } \\
\text { adults and } \\
\text { seeds }\end{array}$ & Brazil & $\begin{array}{l}\text { Microsatellites: } \\
\text { Five loci } \\
78 \text { alleles }\end{array}$ & $\begin{array}{l}\text { Two } \\
\text { continuous } \\
\text { populations } \\
\text { Remnants in } \\
\text { three ranches }\end{array}$ & $\begin{array}{l}\text { 9-37 alleles per } \\
\text { locus } \\
7-28 \text { alleles per } \\
\text { locus }\end{array}$ & $\begin{array}{l}\text { Self-fertilisation } \\
\text { rate }=10 \% \\
\text { Self-fertilisation } \\
\text { rate }=14 \%\end{array}$ & $\begin{array}{l}\text { Mean pollen } \\
\text { dispersal } \\
\text { distance }=212 \mathrm{~m} \\
\text { Mean pollen } \\
\text { dispersal } \\
\text { distance }=1509 \mathrm{~m}\end{array}$ & $\begin{array}{l}\text { Slight increase in I } \\
\text { self-fertilisation in } \\
\text { remnants, but } \\
\text { high pollen } \\
\text { dispersal due to } \\
\text { alien pollinator }\end{array}$ & $\begin{array}{l}\text { Dick et al } \\
\text { (2003) }\end{array}$ \\
\hline $\begin{array}{l}\text { Enterolobium } \\
\text { cyclocarpum }\end{array}$ & Fragmentation & & Seeds & $\begin{array}{l}\text { Northwestern } \\
\text { Costa Rica }\end{array}$ & $\begin{array}{l}\text { Allozymes: } \\
12 \text { polymorphic } \\
\text { loci }\end{array}$ & $\begin{array}{l}\text { One fragmented } \\
\text { population: } \\
9.8 \text { ha core area; } \\
227 \text { ha sampled } \\
\text { in a } 1600 \text { ha } \\
\text { ranch }\end{array}$ & & & $\begin{array}{l}\text { Estimates of } \\
\text { pollen flow } \\
>60 \%\end{array}$ & $\begin{array}{l}\text { Trees receive } \\
\text { pollen from } \\
\text { many donors in } \\
\text { a large network of } \\
\text { reproductively } \\
\text { active individuals }\end{array}$ & $\begin{array}{l}\text { Apsit et al } \\
(2001)\end{array}$ \\
\hline
\end{tabular}


Table A1 Continued

\begin{tabular}{|c|c|c|c|c|c|c|c|c|c|c|c|}
\hline \multirow[t]{2}{*}{ Species } & \multirow[t]{2}{*}{ Impact } & \multirow{2}{*}{$\begin{array}{l}\text { Time since } \\
\text { impact began }\end{array}$} & \multirow{2}{*}{$\begin{array}{l}\text { Material } \\
\text { collected }\end{array}$} & \multirow[t]{2}{*}{ Location } & \multirow[t]{2}{*}{ Marker type } & \multirow{2}{*}{$\begin{array}{l}\text { Number of } \\
\text { populations }\end{array}$} & \multicolumn{3}{|c|}{ Response } & \multirow[t]{2}{*}{ Comments } & \multirow[t]{2}{*}{ Reference } \\
\hline & & & & & & & Diversity & Inbreeding & Gene flow & & \\
\hline E. cyclocarpum & Fragmentation & & Seeds & Costa Rica & $\begin{array}{l}\text { Isozymes: } \\
\text { Five } \\
\text { polymorphic } \\
\text { loci }\end{array}$ & $\begin{array}{l}\text { Populations and } \\
\text { isolated trees } \\
\text { sampled across } \\
\text { the region }\end{array}$ & & $\begin{array}{l}t_{\mathrm{m}}=1.000 \\
t_{\mathrm{m}}=0.999\end{array}$ & & $\begin{array}{l}\text { Similar } \\
\text { outcrossing } \\
\text { rates between } \\
\text { remnants and } \\
\text { continuous } \\
\text { forest: } \\
\text { No restriction } \\
\text { of gene flow }\end{array}$ & $\begin{array}{l}\text { Rocha and } \\
\text { Aguilar } \\
\text { (2001) }\end{array}$ \\
\hline E. cyclocarpum & Fragmentation & & Seeds & Costa Rica & $\begin{array}{l}\text { Quantitative } \\
\text { traits; progeny } \\
\text { vigor and } \\
\text { fruit } \\
\text { set }\end{array}$ & $\begin{array}{l}\text { Comparison } \\
\text { of pasture } \\
\text { trees } \\
(\geqslant 500 \mathrm{~m} \\
\text { from } \\
\text { conspecifics) } \\
\text { and } \\
\text { continuous } \\
\text { forest trees in } \\
\text { forest patches } \\
\text { of } 10 \text { ha }\end{array}$ & \multicolumn{4}{|c|}{$\begin{array}{l}\text { Flowers in continuous forests more likely to have } \\
\text { pollen deposited on stigmas than flowers from trees in } \\
\text { pastures ( } 52.1 \text { vs } 32.3 \% \text {, respectively). Trees from continuous } \\
\text { forests six times more likely to set fruit and produce } \\
\text { more seed per fruit than trees in pastures. Progeny from } \\
\text { trees in continuous forests more vigorous than progeny } \\
\text { from trees in pasture, based on } 12 \text { of } 16 \text { indicators } \\
\text { of plant vigour }\end{array}$} & $\begin{array}{l}\text { Rocha and } \\
\text { Aguilar } \\
\text { (2001) }\end{array}$ \\
\hline $\begin{array}{l}\text { Gliricidia } \\
\text { sepium }\end{array}$ & Fragmentation & & $\begin{array}{l}\text { Leaves and } \\
\text { seeds from } \\
\text { all } \\
\text { individuals }\end{array}$ & $\begin{array}{l}\text { Southern } \\
\text { Guatemala }\end{array}$ & $\begin{array}{l}\text { SSRs: } \\
\text { One locus } \\
\text { Six alleles }\end{array}$ & \multicolumn{2}{|l|}{$\begin{array}{l}\text { One fragmented } \\
\text { population with } \\
\text { an area of } \\
0.16 \mathrm{~km}^{2}\end{array}$} & & $\begin{array}{l}1.8 \% \text { of pollen } \\
\text { transfer occurred } \\
\text { over distances } \\
>75 \mathrm{~m}\end{array}$ & $\begin{array}{l}\text { Small } \\
\text { proportion of } \\
\text { long-distance } \\
\text { gene flow }\end{array}$ & $\begin{array}{l}\text { Dawson } \\
\text { et al (1997) }\end{array}$ \\
\hline $\begin{array}{l}\text { Pachira } \\
\text { quinata }\end{array}$ & Fragmentation & & Seeds & $\begin{array}{l}\text { Northwestern } \\
\text { Costa Rica }\end{array}$ & $\begin{array}{l}\text { Allozymes: } \\
\text { Seven } \\
\text { polymorphic } \\
\text { loci }\end{array}$ & $\begin{array}{l}15 \text { trees from } \\
\text { continuous } \\
\text { forests } \\
15 \text { isolated } \\
\text { trees sampled } \\
\text { across the } \\
\text { region }\end{array}$ & $\begin{array}{l}H_{\mathrm{E}}=0.398 \\
H_{\mathrm{E}}=0.400\end{array}$ & $\begin{array}{l}r_{\mathrm{p}}=0.470 ; \\
r_{\mathrm{p}}=0.740 ;\end{array}$ & & \multirow[t]{3}{*}{$\begin{array}{l}\text { Restricted } \\
\text { gene flow to } \\
\text { isolated trees }\end{array}$} & $\begin{array}{l}\text { Fuchs et al } \\
\text { (2003) }\end{array}$ \\
\hline P. quinata & Fragmentation & & Seeds & $\begin{array}{l}\text { Northwestern } \\
\text { Costa Rica }\end{array}$ & $\begin{array}{l}\text { Reproductive } \\
\text { traits: seed and } \\
\text { fruit set }\end{array}$ & $\begin{array}{l}15 \text { trees from } \\
\text { each of } \\
\text { continuous } \\
\text { forests and } \\
\text { isolated trees } \\
(>500 \mathrm{~m}) \text { in } \\
\text { fields }\end{array}$ & \multicolumn{3}{|c|}{$\begin{array}{l}\text { Fruit set higher in trees in mature forest }(6 \%) \text { than } \\
\text { in trees separated by } 500 \mathrm{~m} \text { from conspecifics }(3 \%) \text {. } \\
\text { Seed production per fruit and total fruit production } \\
\text { not affected by fragmentation }\end{array}$} & & $\begin{array}{l}\text { Fuchs et al } \\
\text { (2003) }\end{array}$ \\
\hline P. quinata & Fragmentation & & Seeds & $\begin{array}{l}\text { Northwestern } \\
\text { Costa Rica, } \\
\text { southern } \\
\text { Honduras }\end{array}$ & $\begin{array}{l}\text { Reproductive } \\
\text { trait: fruit set }\end{array}$ & $\begin{array}{l}\text { Trees in } \\
\text { continuous } \\
\text { forest, forest } \\
\text { fragment and } \\
\text { in pastures }\end{array}$ & \multicolumn{3}{|c|}{$\begin{array}{l}\text { Fruit production (number of capsules) not affected by } \\
\text { degree of disturbance/fragmentation }\end{array}$} & & $\begin{array}{l}\text { Boshier et al } \\
(2004)\end{array}$ \\
\hline
\end{tabular}


Table A1 Continued

\begin{tabular}{|c|c|c|c|c|c|c|c|c|c|c|}
\hline \multirow[t]{2}{*}{ Species } & \multirow[t]{2}{*}{ Impact } & \multirow{2}{*}{$\begin{array}{l}\text { Time since } \\
\text { impact began }\end{array}$} & \multirow{2}{*}{$\begin{array}{l}\text { Material } \\
\text { collected }\end{array}$} & \multirow[t]{2}{*}{ Location } & \multirow[t]{2}{*}{ Marker type } & \multirow{2}{*}{$\begin{array}{l}\text { Number of } \\
\text { populations }\end{array}$} & \multicolumn{2}{|c|}{ Response } & \multirow[t]{2}{*}{ Comments } & \multirow[t]{2}{*}{ Reference } \\
\hline & & & & & & & Inbreeding & Gene flow & & \\
\hline P. quinata & Fragmentation & & Seeds & $\begin{array}{l}\text { Honduras - } \\
\text { Colombia }\end{array}$ & $\begin{array}{l}\text { Quantitative } \\
\text { traits: seed and } \\
\text { fruit set, } \\
\text { germination, } \\
\text { height and } \\
\text { diameter } \\
\text { growth }\end{array}$ & $\begin{array}{l}\text { Test for } \\
\text { outbreeding } \\
\text { depression by } \\
\text { controlled } \\
\text { pollinations. } \\
\text { Pollen sourced } \\
\text { at different } \\
\text { distances from } \\
\text { mother trees } \\
(0 \mathrm{~m}, 50 \mathrm{~m}, \\
250 \mathrm{~m}, 700 \mathrm{~m}, \\
3 \mathrm{~km}, 8 \mathrm{~km}, \\
20 \mathrm{~km}, 70 \mathrm{~km}, \\
300 \mathrm{~km}, \\
1800 \mathrm{~km})\end{array}$ & \multicolumn{2}{|c|}{$\begin{array}{l}1800 \mathrm{~km} \text { crosses showed reduced seed set equal to selfing. } \\
\text { No other variables affected by pollination distance }\end{array}$} & & $\begin{array}{l}\text { Billingham } \\
\text { (1999) }\end{array}$ \\
\hline $\begin{array}{l}\text { Pentaclethra } \\
\text { macroloba }\end{array}$ & Fragmentation & 40 years & $\begin{array}{l}\text { Leaves from } \\
\text { adults and } \\
\text { seedlings }\end{array}$ & Costa Rica & $\begin{array}{l}\text { Allozymes: } \\
\text { Five } \\
\text { polymorphic } \\
\text { loci, } \\
\text { Nine } \\
\text { monomorphic } \\
\text { loci }\end{array}$ & $\begin{array}{l}\text { Seven stands } \\
\text { of continuous } \\
\text { forest in an } \\
1800 \text { ha } \\
\text { reserve } \\
11 \text { fragmented } \\
\text { populations } \\
\text { up to } 70 \mathrm{~km} \\
\text { from reserve }\end{array}$ & $\begin{array}{l}H=0.035-0.064 \\
\text { (adults); } \\
H=0.035-0.048 \\
\text { (seedlings) } \\
H=0.050-0.135\end{array}$ & $\begin{array}{l}F_{\mathrm{ST}}=0.038 \text { (adults) } \\
\text { and } 0.019 \\
\text { (seedlings) } \\
F_{\mathrm{ST}}=0.219\end{array}$ & $\begin{array}{l}\text { Reduced gene } \\
\text { flow due to } \\
\text { spatial } \\
\text { separation }\end{array}$ & $\begin{array}{l}\text { Hall et al } \\
\text { (1994a) }\end{array}$ \\
\hline $\begin{array}{l}\text { Pinus oоcarpa } \\
\text { var. oоcarpa }\end{array}$ & $\begin{array}{l}\text { Logging, } \\
\text { deforestation }\end{array}$ & 20 years & Seeds & Honduras & $\begin{array}{l}\text { Quantitative } \\
\text { traits: germination, } \\
\text { mortality, no. of } \\
\text { cotyledons, } \\
\text { seedling height } \\
\text { and diameter, no. } \\
\text { of buds, survival, } \\
\text { length, and no. } \\
\text { of leaves }\end{array}$ & $\begin{array}{l}\text { Seeds } \\
\text {,collected } \\
\text { from trees in } \\
\text { three different } \\
\text { population } \\
\text { densities (190, } \\
\text { 102, } 7 \text { trees/ha) }\end{array}$ & \multicolumn{3}{|c|}{$\begin{array}{l}\text { With decreased density of adult tree, observed: reduced seed } \\
\text { set, seed weight, germination and late emergency, increased } \\
\text { no. of cotyledons and chlorophyll deficiencies, reduced } \\
\text { seedling height } \\
\text { ) }\end{array}$} & $\begin{array}{l}\text { Madriz } \\
(2004)\end{array}$ \\
\hline $\begin{array}{l}\text { Pithecellobium } \\
\text { elegans }\end{array}$ & Fragmentation & 15 years & $\begin{array}{l}\text { Leaves from } \\
\text { adults and } \\
\text { seeds }\end{array}$ & Costa Rica & $\begin{array}{l}\text { SSRs: } \\
\text { Five loci } \\
42 \text { alleles }\end{array}$ & $\begin{array}{l}28 \text { trees } \\
\text { within a } \\
0.32 \mathrm{~km}^{2} \\
\text { fragment }\end{array}$ & $\begin{array}{l}5-14 \text { alleles per } \\
\text { locus }\end{array}$ & $\begin{array}{l}\text { Average gene flow } \\
\text { distance }=142 \mathrm{~m}\end{array}$ & $\begin{array}{l}\text { Long-distance } \\
\text { gene flow }\end{array}$ & $\begin{array}{l}\text { Chase et al } \\
\text { (1996) }\end{array}$ \\
\hline P. elegans & Fragmentation & 40 years & $\begin{array}{l}\text { Leaves from } \\
\text { adults and } \\
\text { seeds }\end{array}$ & Costa Rica & $\begin{array}{l}\text { Allozymes: } \\
\text { Six polymorphic } \\
\text { loci, eight } \\
\text { monomorphic } \\
\text { loci }\end{array}$ & $\begin{array}{l}\text { Two } \\
\text { continuous } \\
\text { populations } \\
\text { in a } 1500 \text { ha } \\
\text { reserve } \\
\text { Six } \\
\text { fragmented } \\
\text { populations } \\
\text { separated by } \\
\text { up to } 75 \mathrm{~km}\end{array}$ & $\begin{array}{l}H=0.14 \text { and } 0.14 ; \\
R_{e}=1.25 \text { and } 1.29\end{array}$ & $\begin{array}{l}F_{\mathrm{ST}}=0.101 \\
N_{\mathrm{m}}=0.70\end{array}$ & $\begin{array}{l}\text { Restricted gene } \\
\text { flow to isolated } \\
\text { trees }\end{array}$ & $\begin{array}{l}\text { Hall et al } \\
\text { (1996) }\end{array}$ \\
\hline
\end{tabular}


Table A1 Continued

\begin{tabular}{|c|c|c|c|c|c|c|c|c|c|c|}
\hline \multirow[t]{2}{*}{ Species } & \multirow[t]{2}{*}{ Impact } & \multirow{2}{*}{$\begin{array}{l}\text { Time since } \\
\text { impact began }\end{array}$} & \multirow{2}{*}{$\begin{array}{l}\text { Material } \\
\text { collected }\end{array}$} & \multirow[t]{2}{*}{ Location } & \multirow[t]{2}{*}{ Marker type } & \multirow{2}{*}{$\begin{array}{l}\text { Number of } \\
\text { populations }\end{array}$} & \multicolumn{2}{|r|}{ Response } & \multirow[t]{2}{*}{ Comments } & \multirow[t]{2}{*}{ Reference } \\
\hline & & & & & & & Diversity & Inbreeding & & \\
\hline P. elegans & Fragmentation & 40 years & Seeds & Costa Rica & $\begin{array}{l}\text { Reproductive } \\
\text { traits: fruit and } \\
\text { seed set }\end{array}$ & $\begin{array}{l}\text { Two } \\
\text { continuous } \\
\text { populations } \\
\text { in a } 1500 \mathrm{ha} \\
\text { reserve. Six } \\
\text { fragmented } \\
\text { populations } \\
\text { separated by } \\
\text { up to } 75 \mathrm{~km}\end{array}$ & \multicolumn{2}{|c|}{$\begin{array}{l}\text { Lower seed set or failure to set fruit in fragments - low } \% \text { of } \\
\text { trees flowering accentuated by isolation by fragmentation }\end{array}$} & & $\begin{array}{l}\text { Hall et al } \\
\text { (1996) }\end{array}$ \\
\hline \multicolumn{2}{|c|}{ Samanea saman Fragmentation } & & Seeds & $\begin{array}{l}\text { Northwestern } \\
\text { Costa Rica }\end{array}$ & $\begin{array}{l}\text { Isozymes: } \\
\text { Six polymorphic } \\
\text { loci }\end{array}$ & $\begin{array}{l}\text { One } \\
\text { continuous } \\
\text { population in } \\
\text { a } 7550 \mathrm{ha} \\
\text { reserve } \\
17 \text { isolated } \\
\text { trees along } \\
\text { a } 100 \mathrm{~km} \\
\text { distribution }\end{array}$ & Mean $H_{\mathrm{E}}=0.190$ & $\begin{array}{l}\text { Effective self- } \\
\text { fertilisation } \\
\text { rate }=0.010 ; \\
\text { Inbreeding } \\
\text { coefficient }=0.005 \\
\text { Effective self- } \\
\text { fertilisation } \\
\text { rate }=0.088 ; \\
\text { Inbreeding } \\
\text { coefficient }=0.044\end{array}$ & $\begin{array}{l}\text { Higher self- } \\
\text { fertilisation and } \\
\text { inbreeding in } \\
\text { isolated trees }\end{array}$ & $\begin{array}{l}\text { Cascante } \\
\text { et al (2002) }\end{array}$ \\
\hline S. saman & Fragmentation & & Seeds & $\begin{array}{l}\text { Northeastern } \\
\text { Costa Rica }\end{array}$ & $\begin{array}{l}\text { Reproductive } \\
\text { traits; pollen } \\
\text { deposition. } \\
\text { Seed production: } \\
\text { no. of bruchid- } \\
\text { damaged seeds, } \\
\text { no. of aborted } \\
\text { seeds, no. of } \\
\text { undamaged } \\
\text { seeds, total } \\
\text { no. of seeds } \\
\text { developed }\end{array}$ & $\begin{array}{l}27 \text { isolated } \\
\text { trees }>500 \mathrm{~m} \\
\text { from nearest } \\
\text { conspecific } \\
\text { and } \\
\text { surrounded by } \\
\text { agricultural } \\
\text { fields, } \\
\text { pastures, or } \\
\text { small remnant } \\
\text { forest patches } \\
\text { and } 24 \text { trees in } \\
\text { continuous } \\
\text { populations of } \\
\geqslant 10 \text { trees/ha. } \\
\text { surrounded by } \\
\text { undisturbed } \\
\text { forest }\end{array}$ & \multicolumn{2}{|c|}{$\begin{array}{l}\text { Higher probability of flowers in continuous forest to produce } \\
\text { mature fruit }(2.1 \%) \text { compared with isolated trees }(0.4 \%) \text {. Seed } \\
\text { predation by bruchids higher in continuous forest, so number } \\
\text { of viable seeds similar for continuous and fragmented } \\
\text { conditions. Seeds produced by trees from continuous } \\
\text { populations more likely to germinate and produce greater } \\
\text { leaf area and biomass as seedlings than seed from isolated } \\
\text { trees }\end{array}$} & & $\begin{array}{l}\text { Cascante } \\
\text { et al (2002) }\end{array}$ \\
\hline $\begin{array}{l}\text { Spondias } \\
\text { mombin }\end{array}$ & Fragmentation & & Seeds & & $\begin{array}{l}\text { Quantitative } \\
\text { traits: fruit } \\
\text { production, } \\
\text { seed } \\
\text { germination, } \\
\text { seedling height } \\
\text { growth }\end{array}$ & $\begin{array}{l}\text { Three conti- } \\
\text { nuous forest } \\
\text { populations } \\
\text { (old, } 1^{\circ} \\
\text { successional, } \\
\left.2^{\circ}\right) \text {, one large } \\
\text { fragment (4 ha), } \\
\text { six small } \\
\text { fragments } \\
(0.5-1 \text { ha) }\end{array}$ & \multicolumn{2}{|c|}{$\begin{array}{l}\text { Small fragment populations showed significant reductions in } \\
\text { germination rate }(>35 \%) \text { and fruit production relative to } \\
\text { large fragment and continuous forest populations }\end{array}$} & & $\begin{array}{l}\text { Nason and } \\
\text { Hamrick } \\
\text { (1997) }\end{array}$ \\
\hline
\end{tabular}


Table A1 Continued

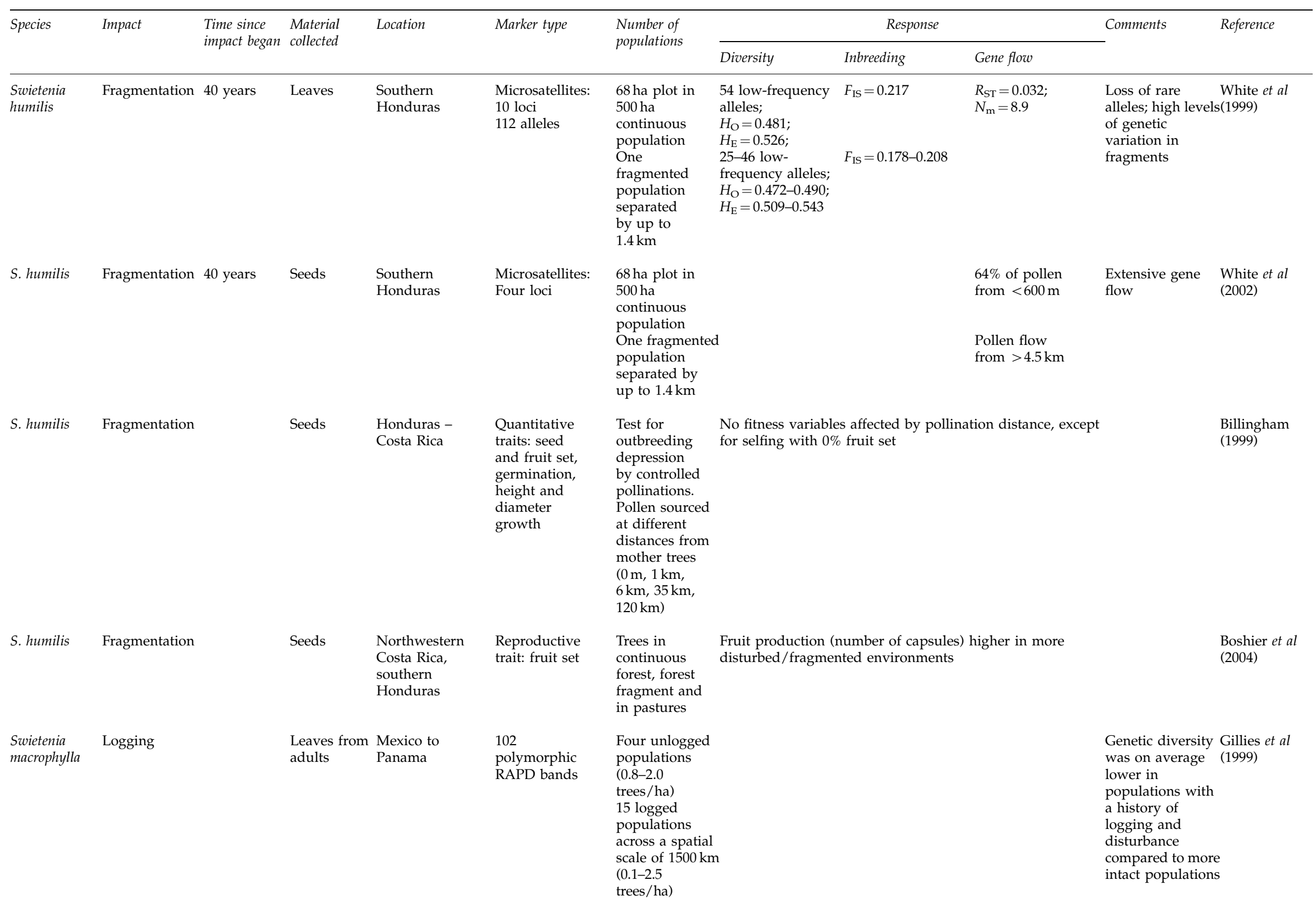


Table A1 Continued

\begin{tabular}{|c|c|c|c|c|c|c|c|c|c|c|c|}
\hline \multirow[t]{2}{*}{ Species } & \multirow[t]{2}{*}{ Impact } & \multirow{2}{*}{$\begin{array}{l}\text { Time since } \\
\text { impact began }\end{array}$} & \multirow{2}{*}{$\begin{array}{l}\text { Material } \\
\text { collected }\end{array}$} & \multirow[t]{2}{*}{ Location } & \multirow[t]{2}{*}{ Marker type } & \multirow{2}{*}{$\begin{array}{l}\text { Number of } \\
\text { populations }\end{array}$} & \multicolumn{3}{|c|}{ Response } & \multirow[t]{2}{*}{ Comments } & \multirow[t]{2}{*}{ Reference } \\
\hline & & & & & & & Diversity & Inbreeding & Gene flow & & \\
\hline S. macrophylla & Logging & 100 years & $\begin{array}{l}\text { Leaves from } \\
\text { adults and } \\
\text { saplings }\end{array}$ & $\begin{array}{l}\text { Northwestern } \\
\text { Costa Rica }\end{array}$ & $\begin{array}{l}\text { Microsatellites: } \\
\text { Five loci } \\
21 \text { alleles }\end{array}$ & $\begin{array}{l}\text { Four } \\
\text { unlogged } \\
\text { sites, } \\
\text { disturbed } \\
\text { typically } \\
\text { by fire } \\
\text { One logged } \\
\text { site }\end{array}$ & $\begin{array}{l}N_{\mathrm{a}}=3.00-4.00 ; \\
N_{\mathrm{e}}=2.22-2.70 ; \\
H_{\mathrm{O}}=0.45-0.58 ; \\
H_{\mathrm{E}}=0.47-0.54 \\
N_{\mathrm{a}}=2.80 ; \\
N_{\mathrm{e}}=2.24 \\
H_{\mathrm{O}}=0.49 ; \\
H_{\mathrm{E}}=0.51\end{array}$ & & $F_{\mathrm{ST}}=0.0631$ & $\begin{array}{l}\text { No } \\
\text { differentiation } \\
\text { between } \\
\text { unlogged and } \\
\text { logged sites }\end{array}$ & $\begin{array}{l}\text { Céspedes } \\
\text { et al (2003) }\end{array}$ \\
\hline S. macrophylla & Logging & & $\begin{array}{l}\text { Leaves from } \\
\text { adults and } \\
\text { seeds }\end{array}$ & $\begin{array}{l}\text { Mexico to } \\
\text { Panama }\end{array}$ & $\begin{array}{l}\text { Microsatellites: } \\
\text { Seven loci }\end{array}$ & $\begin{array}{l}\text { Three } \\
\text { unlogged } \\
\text { populations } \\
\text { Five logged } \\
\text { populations } \\
\text { across a spatial } \\
\text { scale of } \\
1500 \mathrm{~km}\end{array}$ & $\begin{array}{l}H_{\mathrm{O}}=0.533-0.578 ; \\
H_{\mathrm{E}}=0.618-0.681 \\
H_{\mathrm{O}}=0.470-0.672 ; \\
H_{\mathrm{E}}=0.593-0.799 \\
\end{array}$ & & & $\begin{array}{l}\text { Increased } \\
\text { inbreeding } \\
\text { within Central } \\
\text { American } \\
\text { populations } \\
\text { compared to } \\
\text { those from South } \\
\text { America (Lemes } \\
\text { et al, 2003) }\end{array}$ & $\begin{array}{l}\text { Novick et al } \\
\text { (2003) }\end{array}$ \\
\hline S. macrophylla & Logging & & Seeds & $\begin{array}{l}\text { Mesoamerica } \\
\text { Mexico-Panamá }\end{array}$ & $\begin{array}{l}\text { Quantitative } \\
\text { traits; growth } \\
\text { form, height, } \\
\text { diameter, no. } \\
\text { of shoots after } \\
\text { shoot borer } \\
\text { attack }\end{array}$ & $\begin{array}{l}17 \text { grasslands } \\
\text { and home } \\
\text { orchards, five } \\
\text { forest primary } \\
\text { or secondary } \\
\text { forest trees }\end{array}$ & $\begin{array}{l}\text { Reduction in gro } \\
\text { compared to tree }\end{array}$ & $\begin{array}{l}\text { th of proger } \\
\text { in continuo }\end{array}$ & $\begin{array}{l}\text { isolated trees } \\
\text { lations }\end{array}$ & & $\begin{array}{l}\text { Navarro and } \\
\text { Hernández } \\
\text { (2004) }\end{array}$ \\
\hline $\begin{array}{l}\text { Symphonia } \\
\text { globulifera }\end{array}$ & Fragmentation & 10-30 years & $\begin{array}{l}\text { Leaves from } \\
\text { adults, } \\
\text { saplings and } \\
\text { seedlings }\end{array}$ & $\begin{array}{l}\text { Southern } \\
\text { Costa Rica }\end{array}$ & $\begin{array}{l}\text { Microsatellites: } \\
\text { Three loci } \\
55 \text { alleles }\end{array}$ & $\begin{array}{l}3.2 \text { ha plot of } \\
\text { continuous } \\
\text { forest in } 235 \text { ha } \\
\text { reserve } \\
38.5 \text { ha } \\
\text { fragmented } \\
\text { population }\end{array}$ & & $s=0.098$ & & $\begin{array}{l}\text { Increased } \\
\text { selfing in } \\
\text { isolated trees } \\
\text { Genetic } \\
\text { bottleneck } \\
\text { through } \\
\text { reproductive } \\
\text { dominance }\end{array}$ & $\begin{array}{l}\text { Aldrich and } \\
\text { Hamrick } \\
\text { (1998) }\end{array}$ \\
\hline S. globulifera & Fragmentation & 10-30 years & $\begin{array}{l}\text { Leaves from } \\
\text { adults, } \\
\text { saplings and } \\
\text { seedlings }\end{array}$ & $\begin{array}{l}\text { Southern } \\
\text { Costa Rica }\end{array}$ & $\begin{array}{l}\text { Microsatellites: } \\
\text { Three loci }\end{array}$ & $\begin{array}{l}4.2 \text { ha plot of } \\
\text { continuous } \\
\text { forest in } \\
235 \text { ha } \\
\text { reserve } \\
38.5 \text { ha } \\
\text { fragmented } \\
\text { population }\end{array}$ & $\begin{array}{l}H_{\mathrm{O}}=0.73 \\
\text { (seedlings), } \\
0.73 \text { (saplings), } \\
0.77 \text { (adults) } \\
H_{\mathrm{O}}=0.61 \\
\text { (seedlings), } \\
0.74 \text { (saplings), } \\
0.81 \text { (adults) }\end{array}$ & & $\begin{array}{l}R_{\mathrm{ST}}=0.005 \\
R_{\mathrm{ST}}=0.210\end{array}$ & $\begin{array}{l}\text { Inbreeding in } \\
\text { seedlings } \\
\text { resulting in } \\
\text { genetic } \\
\text { differentiation } \\
\text { among remnant } \\
\text { forests }\end{array}$ & $\begin{array}{l}\text { Aldrich et al } \\
\text { (1998) }\end{array}$ \\
\hline
\end{tabular}

